\title{
ARTE \& PERCEPÇÃO: RELAÇÕES ENTRE PINTURA E TEORIAS DA VISÃO ENTRE OS SÉCULOS XV E XVII
}

\author{
Guilherme Mautone ${ }^{1}$
}

\begin{abstract}
RESUMO
Ao longo do texto pretendo sugerir a ideia de que nas escolas Caravaggistas de pintura do século XVII, e em especial nas obras de Georges de La Tour, pode-se encontrar uma espécie de investigação muito peculiar sobre a visão que, poeticamente, incorpora-se através de (a) uma distensão dos princípios renascentistas de confecção imagética cuja exposição técnica e doutrinária remonta ao Da Pintura [Della Pittura] de Alberti, escrito em 1435 e de (b) uma valorização da modelagem a partir da cor e da luz e da sombra. Gombrich (1977), Baxandall (1988) e Burke (1998) são apontados como embasamento para uma concepção de historicidade em termos de modificação dos modos de produção artística; e Darrigol (2012) como responsável por um recenseamento do campo da ótica e das principais teorias da visão desde os pré-socráticos.
\end{abstract}

Palavras-chave: Pintura. Caravaggismo. Teorias da Visão. Estética. Epistemologia.

\begin{abstract}
This paper suggests the idea that in the Caravaggesque schools of painting of the $17^{\text {th }}$ century is possible to find a peculiar investigation about visual perception, especially in the works of Georges de La Tour. This investigation is artistically embodied through: (a) a distension from renaissance principles of image making whose technical and doctrinal exposition goes back to Alberti's Della Pittura (1435); and (b) a valorization of the modelling starting on color and light and dark. Gombrich (1977), Baxandall (1988) and Burke (1998) base a conception of history in terms of modifications on the modalities of artistic production; and Darrigol (2012) is responsible for a genealogy of the field of optics and main theories of vision since the pre-Socratics.
\end{abstract}

Keywords: Painting. Caravagesques. Theories of Vision. Aesthetics. Epistemology.

\footnotetext{
${ }^{1}$ Bacharel, Mestre e doutorando (do $4^{\mathrm{a}}$ ano) em Filosofia pela UFRGS com pesquisa em Filosofia da Arte e Estética. É docente da Casamundi Cultura e Editor da Revista PHILIA | Filosofia, Literatura \& Arte. A pesquisa é financiada pela CAPES e orientada pela Prof ${ }^{a}$. Dra ${ }^{\mathrm{a}}$. Kathrin Holzermayr Rosenfield. guimautone@gmail.com.
} 


\section{Preâmbulo}

A ideia por trás de uma expressão tão pregnante em nossa cultura contemporânea como artes visuais parece, à primeira vista, quase que tautológica. ${ }^{2}$ As artes que se agrupam sob o escopo das chamadas artes visuais são aquelas que só podem ser acessadas e discutidas a partir da experiência visual que com elas travamos. O emprego de uma categoria epistemológica ('visuais') para a delimitação de um conjunto de atividades, embora diversas atualmente (pinturas, desenhos, esculturas, instalações, fotografias, vídeoarte, etc.), pretende, portanto, chamar atenção para o fato de que aquilo que as reúne nesse conjunto consiste no truísmo de que são todas feitas para o olhar. E mais, de que são coisas que, se não forem olhadas, como que perdem sua razão de ser.

Parece-me, entretanto, que as obviedades concernentes a esse tipo de delimitação contemporânea da produção poética e discursiva resguardam uma série de problemas centrais que, quanto mais negligenciados, mais contribuem para a especulação vazia, a ignorância de toda uma milenar tradição reflexiva e para o esgarçamento - cada vez mais sentido - da nossa sensibilidade contemporânea. Pensadores como Ernst Gombrich, Cecil Grayson e Michael Baxandall, por exemplo, que de tempos em tempos passam por verdadeiros períodos de esquecimento dentro dos currículos acadêmicos pois abafados pelas novidades efervescentes e pelos caprichos da crítica, souberam trazer à tona os pontos fulcrais e as dificuldades no estudo das artes. Sobretudo, souberam que a pintura, o desenho, a escultura, avizinham-se ardilosamente das discussões filosóficas sobre a percepção visual e a epistemologia. Vizinhança essa seguidamente elidida pelo emprego um tanto alienante de novos termos. Quais são, por exemplo, as relações perspícuas entre

\footnotetext{
Até onde entendo, a introdução do termo artes visuais veio a substituir a terminologia mais canônica, embora ainda empregada, e que agrupava as produções em desenho, pintura, afresco, escultura, etc. sob o escopo das artes plásticas ou, ainda mais antigamente, das belas artes. O abandono de artes plásticas se dá em função da incorporação de novos suportes que não são per se plásticos, por exemplo, a fotografia e a vídeo-arte. E o abandono de belas artes se dá em função do abandono da beleza enquanto característica essencial do artístico ainda no século XX. Desse modo, o termo artes visuais procura evitar alguns dos mecanismos de descredenciamento intensional de determinados objetos que, legitimamente, merecem a concessão do estatuto de arte ao ajustar as condições de estipulação definicional, não mais estipulando a intensionalidade da 'arte' através da beleza ou da plasticidade.
} 
arte e percepção visual? Qual é a especificidade das artes visuais e, em que sentido, elas oferecem oportunidades de problematização da própria percepção visual? Ou, então, em que sentido elas dependem, em sua confecção, de uma certa subvenção às discussões milenares sobre a percepção, sobre a visão e sobre a ótica? Quais as consequências dessas problematizações para nossas concepções - por vezes tão estereotipadas - sobre a história e a teoria das artes? E quais são, por fim, os modos através dos quais os artistas ousaram colocar poeticamente em suas obras tais questões?

Ao longo desse texto pretendo explorar algumas relações entre a produção artística, em especial a pintura, e as discussões teóricas sobre a visão, em especial a ótica. Localizo nas escolas Caravaggistas de pintura do século XVII a presença de uma verdadeira investigação - elaborada via arte, via uma poética - das relações entre confecção imagética e ótica, especialmente no que diz respeito ao trabalho do claro e do escuro [chiaroscuro] e na escolha tonal. Compreendo a predominância do trabalho tonal entre os Caravaggistas enquanto uma espécie de distensão daqueles princípios paradigmáticos da pintura elaborados no Quattrocento e no Cinquecento por, respectivamente, Alberti e Vasari quando estipularam o desenho [disegno] e a perspectiva linear [perspectiva pingendi] como o modo, o caminho ou a maneira [maniera] de construção legítima [contruzione legittima] da pintura. Alberti, sobretudo em Da Pintura, [Della pittura] escrito em vernáculo em 1435, efetuou uma verdadeira incorporação dos princípios geométricos de Euclides e das teorias óticas de Alhazen ao escrever seu tratado destinado à qualificação do trabalho técnico dos pintores, indicando com isso a aplicação das possibilidades de geometrização e de coerência empírica na prática de confecção imagética de tendência naturalista. Assim, em minha sugestão, será essa tendência que se distenderá entre os pintores Caravaggistas ao preconizarem o trabalho da luz e da sombra em detrimento do desenho e da perspectiva linear.

Menciono desde já que ao longo do texto lanço mão da concepção semiótica da arte avançada por Ernst Gombrich em Arte e Ilusão, de 1977, no intuito de embasar essas distensões, mutações, abandonos e retomadas dos modos de confecção imagética ao longo dos séculos enquanto condições de possibilidade da própria história da arte. Não sem surpresa, encontro po- 
sição semelhante - dadas certas particularidades e interesses - nos empreendimentos de Umberto Eco, em seu Obra Aberta, de 1962. Ou seja, a explicação da historicidade da arte na concepção gombrichniana se efetua principalmente através da sugestão de mudanças intrínsecas em seus modos de produção que geram, consequentemente, novas exigências apreciativas e interpretativas. Concepções no mesmo espírito podem ser encontradas mais recentemente em Michael Baxandall (1988) e em Peter Burke (1998), embora Baxandall endosse complementarmente uma explicação das especificidades do Renascimento em termos materialistas. Também recorro à genealogia do campo da ótica realizada por Darrigol (2012) no intuito de dimensionar mais adequadamente as teorias sobre a percepção sensível e sobre a visão vigentes entre os séculos XV, XVI e XVII.

A segunda seção é reservada a uma discussão sobre a elaboração doutrinal dos princípios de confecção imagética no Quattrocento por Alberti; bem como a uma discussão sobre a notória nomeação, feita por Vasari no Cinquecento, do período como uma renascença [rinascità]. E a terceira seção é reservada a uma discussão sobre as escolas Caravaggistas, mas sobretudo sobre a pintura de Georges de La Tour.

\section{Uma janela aberta para o mundo e um olhar renascente}

Uma das mais pregnantes delimitações históricas da arte com a qual ainda hoje se trabalha e se discute consiste naquela oferecida por Jacob Burckhardt no advento da publicação de seu livro homônimo, A Cultura do Renascimento na Itália (Die Cultur der Renaissance in Italien) de 1860. Ainda hoje ao nos referirmos ao Renascimento lançamos mão de uma espécie de explicação tipicamente burckhardtiana do período que, através da introdução de uma categoria psicológica, pretende sugeri-lo em termos da conquista de uma individualidade naturalista capaz de suspender um suposto estado de alienação dos homens e mulheres medievais circunscrito pela ideia de uma comunhão total com Deus (Burckhardt, 1991: 81-93). No entanto, a replicação atual e já descarnada de autoria dessa concepção particular não mais dimensiona as complexas heranças de ideias e doutrinas que paulatinamente se sedimentaram até que fosse possível, em pleno século 
XIX, compreender o Renascimento enquanto saída humanista da obscuridade medieval. Essa ideia, além de anacrônica, é caricatural. E já não leva mais em conta as suas heranças filosóficas.

Esse naturalismo que Burckhardt reinventa e a ele ajunta a ideia forçosa de uma nascente autoconsciência tem uma longa tradição na história da cultura ocidental que, embora Burckhardt não explicite com exatidão, remonta não só aos primeiros pensadores do Quattrocento e do Cinquecento que ousaram periodizar um tempo ainda presente, mas igualmente aos pensadores do helenismo. Foi Vasari, por exemplo, o primeiro a empregar com legitimidade o termo renascimento [rinascità] em 1550 para referir-se aos séculos XV e XVI (respectivamente, o Quattrocento e ao Cinquecento). Bem como foi Vasari quem empregou o termo natural - mas nunca naturalismo - em ocasiões bastante específicas ao falar dessa renascença, sempre referindo as maneiras, os modos e as competências técnicas ou artísticas. Assim, natural para Vasari era o desenho de Giotto que, sobre o nariz de uma das figuras pintadas por Cimabue, seu professor, prega-lhe uma peça ao desenhar nela uma mosca tão natural que seu mestre tenta espantá-la (Vasari, 1991: 15-34). Naturais e vívidas eram também as guirlandas e as frutas de Luca Della Robbia, capazes projetarem-se naturalmente para fora dos desenhos (Vasari, 1991: 72). É, portanto, desse modo que o naturalismo aparece no jargão descritivo sobre a arte e os artistas, como uma forma de descrever suas habilidades, suas inovações técnicas, sua genialidade no desenho. A leitura de Burckhardt, sobrevalorizar os termos psicológicos dessa nova concepção de mundo naturalista para o homem da Renascença, esquece-se dessa particular herança vasariana.

Retomar As vidas dos mais excelentes arquitetos, pintores e escultores italianos (Vita de'più eccellenti architetti, pittori et scultori italiani) escrita por Vasari em 1550 implica retomar também aquilo de mais originário e perspicaz em sua proposta, a saber, ter estabelecido volens nolens os primeiros fundamentos de um campo que viria mais tarde a se constituir como a história da arte. Porque é a Vasari que se outorga contemporaneamente a responsabilidade por ter assentado os fundamentos dessa disciplina. 
começou a escrever eram extremamente assistemáticos e não existiam trabalhos que fossem, de fato, referências para guiá-lo através do desconcertante número de artistas e obras desde o tempo de Cimabue até o dele. Não seria algo subestimado afirmar que ele inventou a disciplina da história da arte (Bondanella \& Bondanella, 1991, p. 9). ${ }^{3}$

O livro de Vasari, encomendado por Cosimo de' Medici, consiste numa espécie de coleção de narrativas e estórias sobre a vida de grandes artesãos florentinos, entremeadas com discussões comparativas dos trabalhos dessas figuras com a arte gótica do período medieval (que Vasari denominava de bárbara) e com a arte grega e bizantina. A partir da sua engenhosidade criativa e de seu conhecimento enciclopédico sobre as produções artísticas do período e sobre as heranças góticas e helênicas, é que Vasari lançará sua proposta de periodização dos séculos XIV, XV e metade do XVI através da introdução da noção de maneira [maniera] do artesão [artigiano].

$\mathrm{Na}$ falta de um robusto aparato acadêmico de tomos, artigos e catálogos - disponíveis aos historiadores hoje em dia - Vasari foi forçado a depender da sua própria mente histórica e sua aguda memória visual. Ele concebeu que a primeira tarefa de todo historiador era a de fazer distinções entre os artistas através da qualidade e do estilo de suas obras de artes e, com isso, explicando a evolução da arte do Renascimento italiano através de uma concepção orgânica de seu desenvolvimento (Bondanella \& Bondanella, 1991, p. 9).

Desse modo, a tarefa de tornar inteligível toda uma constelação de produções artísticas ao longo de um número razoável de décadas e séculos seria primeiramente realizada ao se apontar para as principais similaridades e diferenças dessas produções. É com a introdução das noções de modo, maneira ou de estilo que Vasari encontra a categoria estruturante para a fundamentação da análise de suas estórias e biografias. Encontrar, portanto, uma categoria que estruture a própria análise do tempo significa, parece-nos, também sugerir um fundamento para a historicidade do período que Vasari passará a denominar de Renascença, uma vez que é a categoria da maneira (modo ou estilo) que estruturará o que há de distintivo entre produções que se espraiam ao longo de décadas e séculos. Ademais, a compreensão da historicidade em termos de maneira (modo ou estilo) parece também assentar a ideia de que a especificidade histórica de determinado período pode ser exTodas as citações de obras escritas em idiomas que não o português ao longo deste artigo foram feitas por mim e, portanto, são de minha inteira responsabilidade. 
plicada a partir daqueles aspectos fenomenologicamente acessíveis das produções, o que inaugura pela primeira no pensamento ocidental as bases para uma historiografia estilística da história da arte. Cito Vasari:

E a pintura empreendeu em nossos dias os mesmos avanços que um dia empreendeu a escultura, pois aqui o mais excelente Masaccio abandonou completamente o estilo de Giotto e encontrou um novo estilo para [desenhar] suas cabeças, roupagens, nus, coloridos e escorços. E ele deu à luz àquele estilo moderno que foi seguido desde seu tempo até o nosso tempo por todos nossos artistas e que foi enriquecido e embelezado de tempos em tempos com maior graça, melhor invenção e a mais arrojada decoração. Isso ficará evidente em detalhe ao longo das vidas dos artesãos, onde reconheceremos um novo estilo na coloração, no escorço e nas poses mais naturais; uma figuração mais altamente expressiva de sentimentos e gestos físicos combinada com uma tentativa de fazer com que os desenhos reflitam a realidade dos fenômenos naturais; e expressões faciais que se assemelham aos homens que as inspiraram e que foram conhecidos dos artesãos que as pintaram. Dessa maneira os artesãos procuraram produzir o que eles viam na Natureza e nada mais; dessa maneira as suas obras se tornaram bem mais contempladas e bem mais compreendidas; e isso lhes deu coragem de estabelecer regras para a perspectiva e de fazer os seus escorços exatamente como as formas mais próprias dos relevos naturais, enquanto procediam observando o escuro, a luz, os sombreamentos e outros tantos detalhes complexos, e de compor as suas cenas com a mais alta similitude; e eles procuraram fazer suas paisagens mais semelhantes a realidade, assim como suas árvores, relvas, flores, céus, nuvens e outros fenômenos naturais. Eles realizaram isso tão bem que se pode declarar em alto e bom tom que essas artes foram não só melhoradas, mas também foram conduzidas a floração de sua juventude, que promete gestar os seus frutos no porvir e, em um curtíssimo tempo, alcançar a idade da sua mais alta perfeição (Vasari, 1991, p. 57).

O entusiasmo da prosa de Vasari não deixa dúvidas em relação à dimensão de sua proposta. Se há nele uma explicação em termos naturalistas para o Renascimento, conforme pretendeu Burckhardt, ela deverá ser compreendida como estando circunscrita às modificações estilísticas do período; capazes de confeccionar imagens com poses mais naturais que atestavam uma maior atenção do artesão à natureza em suas características observáveis e em seus fenômenos. A maneira moderna de fazer a imagem e que atinge sua excelência orgânica com Masaccio é marcada principalmente por um domínio técnico na (1) modelagem do corpo, dos acessórios, rouparia, cenários, cores e escorços (habilidade de reduzir no desenho o objeto desenhado mantendo fielmente suas proporções); na (2) capacidade de discriminação e 
de reprodução do comportamento das fontes luminosas; e, por fim, sobretudo na (3) aplicação de regras estabelecidas para a perspectiva, garantindo o sucesso do próprio desenho [disegno]. A maestria desse estilo moderno será para Vasari o indício de um grande arrojo técnico entre os artistas de seu tempo que frutificarão nos próximos períodos uma idade de perfeição, corroborando assim com a introdução feita por ele de um tópos orgânico de explicação histórica, de evolução e desenvolvimento sucessivos. A metáfora orgânica para explicação da história, como se ela se comportasse feito um corpo biológico que progressivamente encena sucessivas etapas de maior integração e perfeição, confere uma nuance teleológica à historiografia estilística de Vasari, como se o estilo passasse por modulações evolutivas na produção artística atingindo graus mais elevados de confecção imagética ao longo da sucessão temporal. Nesse sentido, a alusão de Vasari ao procedimento de elaboração das regras exatas de perspectiva que permitem render o desenho com naturalidade correspondem a uma etapa de elevado desenvolvimento dentro da sua periodização.

A edição final de $A s$ vidas... encontra-se estruturada também através da longeva teoria dos três estágios de desenvolvimento artístico na Itália Renascentista. Um primeiro estágio, marcado pelo recrudescimento da grande arte prévia a destruição de uma civilização clássica, foi concretizado pelas inovadoras descobertas estilísticas de Cimabue e Giotto. Sequencialmente, técnicas mais sofisticadas de desenho e de perspectiva levaram a um segundo estágio de aumento das habilidades artísticas, refletido no aumento de regras rigorosas de pintura, escultura e arquitetura. Esse período intermediário no caminho à perfeição absoluta foi dominado por figuras como Ghiberti, Brunelleschi, Donatello e Masaccio. Finalmente, séculos de crescimento e desenvolvimento culminaram na perfeição superlativa de um terceiro período, dominado pela genialidade de Leonardo, Rafael e, sobretudo, pela figura daquele bastião artístico que foi Michelangelo Buonarroti. A interpretação de Vasari sobre seu objeto de estudo foi documentada e argumentada de modo tão persuasivo que ela, em larga medida, permaneceu [até hoje] como uma visão dominante da Itália Renascentista (Bondanella \& Bondanella, 1991, p. 10).

A incorporação por Vasari da ideia de uma necessária elaboração das regras de perspectiva para sua posterior aplicação no desenho, entendido como característica invariável da produção pictórica ou como maneira ou estilo da confecção imagética, evidencia a adesão do pai da história da arte aos preceitos doutrinais da exposição das regras de perspectiva e sua aplica- 
ção na composição das imagens. Assim, a maneira de desenhar e de perspectivar as imagens celebrada por Vasari em sua periodização estilística evidencia também sua adesão integral ao tratado Da Pintura (Della Pittura) escrito por Alberti em 1435, bem como a sua defesa da perspectiva como método standard de resolução das artes visuais do período.

A representação imitativa efetuada através da pintura ou do afresco tem estipulada, portanto, a condição necessária de sua confecção - a saber, a da perspectiva linear [perspectiva pingendi] enquanto construção legítima [construzione legittima]. Darrigol (2012), contudo, parece sugerir que a incorporação da perspectiva linear enquanto maneira de construção legítima da imagem no Renascimento não foi uma técnica que surgiu ex nihilo, porém traçou a sua própria história. Uma história que remonta ao cenário de reintrodução das obras dos pensadores clássicos no período medieval, onde a ótica, então chamada simplesmente de perspectiva, uma ciência da luz e da visão, estava em vias de se consolidar:

A Europa dos séculos XII e XIII experimentou uma profunda transformação cultural através das numerosas traduções do grego e do árabe [...]. Enquanto que mais tardiamente a teologia cristã havia se comprometido com a difusão e com o desenvolvimento da filosofia grega, os novos eruditos do século XII estavam ávidos em aprender através da natureza e das fontes antigas e estrangeiras. No domínio da perspectiva, Alberto, o grande, promoveu e expandiu as doutrinas aristotélicas. Os tratados de Roger Bacon ofereceram uma teoria sincrética da visão, adicionando elementos platônicos e aristotélicos ao De aspectibus de Alhazen. Em particular, Bacon subsumiu a ideia de Alhazen sobre um meio transmissor de formas de luz e cor sob o conceito aristotélico de multiplicatio specierum, que implicou na replicação ordenada de quaisquer qualidades distribuídas espacial ou temporalmente do objeto (as species) de uma camada do meio para a outra. [...] O espírito dessa recepção foi mais conciliador que crítico. Os raios visuais sobreviveram graças à popularidade de Euclides e Ptolomeu. As mais arbitrárias partes do sistema de Alhazen, como a perpendicularidade dos raios eficientes ou a sensibilidade da glacialis, permaneceram indisputadas (Darrigol, 2012, p. 21).

$\mathrm{O}$ intenso debate que permeia a perspectiva foi fruto da recepção e da transmissão das obras da antiguidade, bem como das contribuições árabes, nos séculos XII e XIII. Platão, Aristóteles e Alhazen foram pensadores salutares para a compreensão dessa recepção. Aristóteles incorpora, por exemplo, no De Anima, um tratado sobre a alma no qual realiza uma verda- 
deira análise das funções anímicas de tudo que é dotado de vida, a ideia platônica de que a percepção visual só se realiza mediante a admissão de um meio homogêneo entre o olho e o objeto olhado cujo nome é transparente. Esse meio será analisado como luz quando em atividade, ou seja, como aquilo que ajuda a garantir o nexo causal da percepção sensível; ou seja, o ponto inicial de toda a explicação epistemológica do conhecimento (Aristóteles, 2012: 87, 418b3). Também se encontra no De Anima de Aristóteles aquela sugestiva metáfora do sinete e da cera através da qual o Estagirita pretende explicar em termos intencionais o conteúdo (a atinência, a sobrecidade) da percepção em geral:

No geral e em relação a toda a percepção sensível, é preciso compreender que o sentido é o receptivo das formas sensíveis sem a matéria, assim como a cera recebe o sinal do sinete sem o ferro ou o ouro, e capta o sinal áureo ou férreo, mas não como ouro ou ferro. E da mesma maneira ainda o sentido é afetado pela ação de cada um: do que tem cor, sabor ou som; e não como se diz ser cada um deles, mas na medida em que é tal qualidade e segundo a sua determinação (Aristóteles, 2012, p. 101, 424a16)

Será em relação a doutrina aristotélica de transmissão das formas sem a matéria, dependente por sua vez do hileomorfismo ontológico de Aristóteles (onde as coisas existentes são compósitos de forma e de matéria), que os interpretes medievais farão incidir uma leitura da percepção sensível e da explicação dos processos abstrativos em termos de species sensíveis e intelectuais, capazes de explicarem os processos cognitivos em termos da intencionalidade cognitiva. Assim, o fundamento

da síntese neo-aristotélica em psicologia pretendeu que os fenômenos psicológicos fossem explicados em termos de mecanismos mentais interiores (...). No caso da cognição, esses mecanismos semiautônomos se encontram causalmente conectados uns aos outros e são analisados em termos de potência e ato; suas existências e naturezas são deduzidas das funções que desempenham. Tipicamente, esses módulos mecânicos usualmente designados por 'faculdades' - transferem ou transduzem informação num processo que os escolásticos descreveram como a 'transmissão da forma'. E o veículo para a forma é uma espécie de representação mental, chamada species, que promove mediações entre as diversas faculdades da mente. Portanto, a melhor explicação para os fenômenos psicológicos, ou pelo menos para a cognição, é dada por mecanismos impessoais funcionalmente definidos e que operam, atuam, sobre as representações (King, 2015, p. 102). 
É, portanto, dentro deste contexto continuado de debate epistemológico com fontes antigas que a perspectiva, como ciência da luz e da visão, passou a se consolidar ao longo da passagem dos séculos XIII, XIV e XV. E nessa consolidação passou a ser também elaborada e aplicada em outros contextos, inclusive o da produção imagética. Darrigol (2012) sugere da seguinte maneira a sua incorporação no debate sobre a confecção artesanal das imagens:

Nos séculos XIV e XV, a escolástica pareceu ter diminuído seu interesse em ótica geométrica ou em perspectiva [...]. A multiplicação das species de Bacon invadiu a filosofia natural, com pouco benefício geométrico, mas com forte suporte para a tese da intromissão. A perspectiva reapareceu em vários contextos renascentistas, incluindo a perspectiva artística, anatomia ocular, astronomia e o entretenimento popular (Darrigol, 2012, p. 21).

E ainda:

Uma das consequências do movimento naturalista que acompanhou a retomada do aprendizado no século XIII, foi o fato de que pintores procuraram a representação realista através da perspectiva, da luz e da sombra. Em seus belos afrescos [de 1310] na Capela Arena de Padova, Giotto foi pioneiro da perspectiva linear sem dar a ela nenhuma teorização. Um século mais tarde [no século XV, Quattrocento], o arquiteto florentino Brunelleschi, segundo se diz, deu a primeira teoria da perspectiva, embora o crédito para sua exposição sistemática tenha sido dado a Alberti. Em seu Della Pittura (1435), Alberti explicou como o artista obtém a perspectiva correta através da projeção cônica da cena no plano da representação. Dürer, mais tarde, ofereceu representações impressionantes de aparelhos concretos que Alberti imaginou para esse propósito. Essa teoria plausivelmente desdobrou-se da perspectiva angular compartilhada pelas óticas de Euclides, Ptolomeu e Alhazen, embora a pesquisa de técnicas de cenografia também tenha desempenhado importância (Darrigol, 2012, p. 2223).

De maneira similar, Corrada (2005) parece concordar com Darrigol

(2012) no que diz respeito à influência das explorações geométricas e matemáticas na consolidação da perspectiva:

Inventada no Quattrocento por Brunelleschi, essa técnica [da perspectiva] logo fez surgir uma concepção que satisfez os critérios mais básicos para teorias científicas. Sua primeira formulação, por Leon Battista Alberti, evidenciou a chave geométrica [aquela dos Elementos de Euclides] capaz de proporcionar consistência e fundamentação ao associar a perspectiva com a ótica medieval não através de uma teoria do processo visual, mas através de um 
tratamento geométrico da luz. O próximo passo foi então identificar no olho o centro de projeção. Isso levou à crença popular de que para ver o efeito adequado da perspectiva numa figura [profundidade], o espectador deveria estar localizado exatamente no ponto de projeção. Logo depois da invenção da perspectiva, a ideia do cone projetivo levou a consideração das sombras enquanto instâncias do mesmo esquema. A sombra de um objeto é uma imagem no plano daquele objeto quando nele se projeta uma fonte luminosa, como descreveriam Alberti e Leonardo (Corrada, 2005, p. 316-318).

Embora Darrigol (2012) e Corrada (2005) claramente indiquem a recepção das antigas teorias sobre a visão inscritas sob o escopo das investigações epistemológicas de Platão e, sobretudo, de Aristóteles como relevantes para a consolidação da ciência da perspectiva; eles também parecem indicar que a recuperação dos fundamentos geométricos em Euclides, Ptolomeu e Alhazen desempenhou um papel decisivo para a perspectiva, especialmente em sua aplicação prática na confecção imagética através do Da Pintura de Alberti.

Para sumarizar, as traduções medievais tardias das fontes árabes permitiram a integração europeia da teoria intromissiva da visão de Alhazen, baseada na ideia da projeção cônica de objetos luminosos sobre um humor cristalino e sensitivo. Como essa teoria podia ser facilmente refraseada na linguagem aristotélica das species, ela tornou-se parte essencial do aprendizado escolástico sob o nome de perspectiva. As óticas de Euclides e Ptolomeu eram, não obstante, ensinadas em parelelo, e ainda haviam discussões sobre raios visuais no fim da Idade Média. No Renascimento, o florescimento das artes e das técnicas intensificou o interesse na perspectiva e sugeriu, com isso, analogias entre o olho e os óculos ou o olho e a camera obscura (Darrigol, 2012, p. 25).

Torna-se, portanto, bastante manifesta a complexa rede de intersecções e de influências mútuas tecida entre os desenvolvimentos na ótica, as discussões filosóficas sobre a visão e sobre os processos e funções cognitivas e entre as fundamentações geométricas da perspectiva desde Euclides. O interesse dos séculos XIV e XV por esses debates incide, desse modo, no campo do ensino e da produção das artes, encontrando em Alberti o protagonismo de um tratamento fundamentado.

A verdadeira originalidade de Alberti consiste em reduzir ao essencial as teorias anteriores [sobre a visão, a ótica e a perspectiva], transferindo-as da medicina e metafísica para o campo bem diferente e mais prático da arte. Com o Da Pintura (...) tem-se a primeira aplicação racional e coerente de uma teoria 
empírica da visão humana à arte e à técnica da pintura. Confluem, portanto, no Da Pintura, de um lado, as tendências naturalísticas da arte e, de outro, o interesse renovado, na passagem dos séculos XIV e XV, pelo estudo e o ensino da óptica. (...) Da conjunção de ciência e arte, de óptica e pintura, na formação de Alberti, e do conceito da pintura como imitação e representação de coisas e figuras em suas corretas relações espaciais, nasce a famosa visualização da pintura como uma janela através da qual o espectador olha, de uma determinada distância, a cena que se lhe apresenta 'fora'. A essa 'janela' corresponderia a intersecção da pirâmide visual (que se estende do olho às coisas 'vistas'), isto é, a superfície sobre a qual será feita a pintura. O Livro I do Da Pintura é sobretudo consagrado a explicar esse conceito e as regras e processos necessários para sua execução (Grayson, 1999, p. 5859).

Aquela ideia de Alberti da pintura enquanto janela para o mundo, consagrada no uso corrente do termo janela renascentista, chama a atenção para a resolução da imagem num estilo naturalista mediante a aplicação de uma série de regras composicionais que indicam ao artesão com clareza o escorço correto dos objetos de uma cena quando olhados de um ponto específico. Assim, essa tentativa de algoritmização - pois na construção legítima de Alberti se estabelecem regras fixas que podem ser aplicadas sub-repticiamente a diferentes contextos - depende do estabelecimento de alguns elementos necessários como, por exemplo, o ponto de fuga único e o ponto de projeção, ou central. O ponto de fuga determina o destino das ortogonais que espelham o cone projetivo ou a pirâmide visual do próprio funcionamento do olho. E o ponto central ou de projeção é o estabelecimento do ponto ideal onde deve estar localizado o centro do olho para que a ilusão de profundidade e o escorço dos elementos pareçam adequadamente formados. 




Figura 1

Alberti, Della Pittura, 1804, p. 147
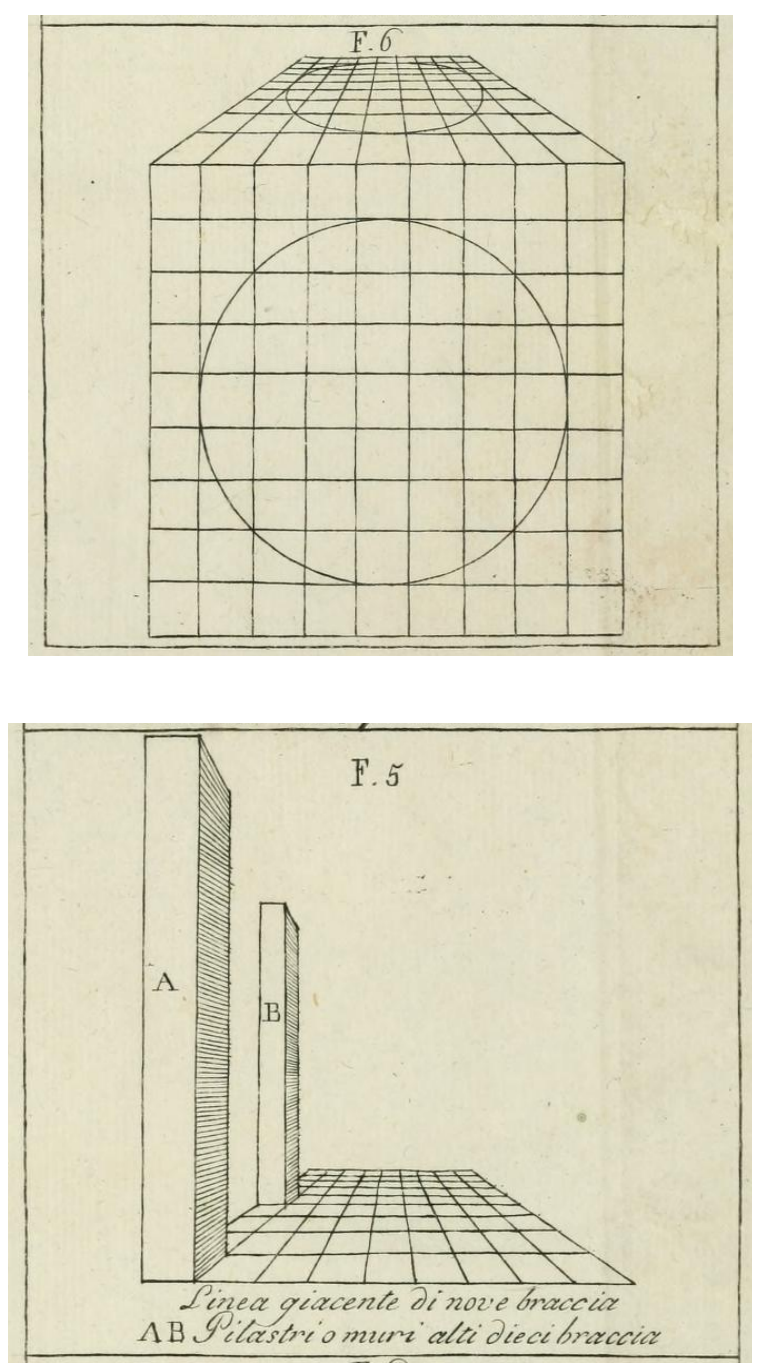

Figuras 2 e 3

Alberti, Della Pittura, 1804, p. 147. 
Assim, a figura 1 apresenta a sugestão de como compor o gradeamento, na etapa de preparação do desenho, e que orientará a confecção da própria imagem, estabelecendo o ponto de fuga, o ponto de projeção, as ortogonais a simularem a pirâmide visual e as paralelas que orientarão a proporcionalidade dos elementos ao fazer o escorço. As figuras 2 e 3, também das primeiras edições do Da Pintura, apresentam duas situações de 'deformação' geométrica das imagens no método da perspectiva linear. A esfera, por exemplo, quando ingressa no algoritmo de perspectivação, deverá ser desenhada numa forma elíptica. E as colunas que, embora tenham o mesmo tamanho, para serem naturalissimamente desenhadas em profundidade, precisam parecer de tamanhos distintos, sendo tal distinção estabelecida por regras rigorosas de medida e de escorço.

Também no próprio Da Pintura se evidencia a dimensão que o tratamento matemático e geométrico da pintura tomava e como ele foi formalizado por Alberti. A perspectiva recebe a qualificação de um supremo engenho, capaz de rivalizar até mesmo com os mestres da antiguidade clássica. Além disso, Alberti deixa bastante evidente toda a preparação matemática que precede, no livro I, a aplicação da perspectiva ao desenho e às técnicas de composição, nos livros II e III. De tal modo que o livro I - integralmente matemático - inicia com uma constatação sobre a indivisibilidade do ponto.

Mas, depois que, de um longo exílio em que os Alberti envelheceram, voltei a esta minha pátria, a mais bela entre as demais, e compreendi que em muitos homens (...) como Nencio, Luca e Masaccio, existe um engenho capaz de realizar qualquer obra de valor e de rivalizar com qualquer artista antigo e famoso (Alberti, 1999, p. 71-72).

E também:

Verás [aqui] três livros: o primeiro, todo matemático, faz surgir das raízes da natureza esta graciosa e tão nobre arte; o segundo põe a arte na mão do artista, distinguindo suas partes e demonstrando tudo; o terceiro estabelece o que e como fazer para obter o domínio e o conhecimento perfeito da pintura (Alberti, 1999, p. 73).

Portanto a ideia da pintura enquanto janela aberta para o mundo oferecida por Alberti ganhou seus contornos mediante a preparação de um terreno fértil e semeado por discussões já seculares sobre ótica, visão, 
epistemologia e matemática. A experiência vívida das obras de arte do passado também sugeriu tanto a Alberti, como a Vasari, a existência do estilo, de uma maneira de confeccionar a imagem naturalista, sempre capaz de sugerir a profundidade e, com isso, sugerir também a pintura enquanto uma emulação da experiência visual - daí a noção de janela aberta para o mundo, bem como a harmonização com as definições miméticas de arte que se coadunavam com as heranças aristotélicas e platônicas sobre o conceito de arte. Era o estilo naturalista que, perdido pela imagética simbólica e protocolar do período medieval, renascia entre os florentinos, levando Vasari a pensar os séculos XIV, XV e XVI enquanto uma Renascença dos modos de produção da imagem clássicos.

\section{Arrefecimento da construção legítima diante da exploração do chiaroscuro}

Em Platão e em Aristóteles encontramos teorias sobre a natureza do artístico que conceberam uma definição de arte em termos miméticos, ou seja, de arte enquanto imitação [mímesis] ${ }^{4}$ Esses empreendimentos teoréticos estavam como que harmonizados com a produção artística da antiguidade, uma vez que entre os gregos do período clássico encontramos obras de arte que, em sua feitura, realizavam imitações naturalistas das coisas. Por outro lado, a produção da arte gótica, em especial a confecção imagética no período do Medievo, certamente remodela esse sentido clássico da arte porque passa a transformar as imitações típicas da antiguidade em signos de natureza simbólica que eram determinados convencionalmente. Esse processo de modificação da arte clássica é aludido por Gombrich (2007):

Em Arte e Ilusão, não fiz mais que aludir aos acontecimentos importantes que acarretaram o fim da arte clássica, mas não é preciso dizer que o contexto mental que contava com a mimese estava em conflito com a nova religião - o cristianismo -, que herdara dos judeus a proibição do Decálogo: "Não farás para ti imagem de escultura nem semelhança de qualquer coisa" - uma proibição voltada especialmente contra a fabricação de ídolos. (...) A mesma rejeição da mimese está contida no preceito do Papa

\footnotetext{
Competem a Platão e a Aristóteles os primeiros empreendimentos definicionais em relação à arte, delimitando o artístico como envolvendo necessariamente a produção de imitações (mímesis). Encontramos essas delimitações, sobretudo, no Livro X da República de Platão, como na Poética de Aristóteles.
} 
Gregório, o Grande, de que "a pintura apresenta ao iletrado o que a escrita proporciona aos que sabem ler". O contexto mental que esse preceito exigia resultaria na transformação das imagens em sinais convencionais. Na medida em que se pode aplicar essa generalização, foi isso que aconteceu na Baixa Idade Média, até que o pêndulo oscilou de volta e a imagem substituiu novamente o sinal (Gombrich, 2007, p. 23).

Por sua vez, Vasari, no século XVII, diante da tarefa de relatar a especificidade das inovações artísticas e técnicas realizadas pelos grandes nomes italianos dos séculos XIV, XV e XVII, sugeriu que esse período fora marcado pelo renascimento de uma maneira antiga, clássica, de confeccionar a imagem, uma maneira que imitava com perfeição naturalista as coisas imitadas, reinstaurando no campo técnico e artesanal da fabricação imagética aquelas celebradas competências dos artesãos antigos, eternizadas por Plínio, o velho, na famosa cena de sua Naturalis Historiae, onde Zêuxis, o grande pintor grego do século V a.C., ao exibir a sua pintura de cachos de uva acabou por enganar até mesmo os passarinhos que vieram bicá-las. Vasari, portanto, como que inaugura o campo da história da arte ao entender a tarefa de periodização de produções técnicas e artísticas através da discriminação de aspectos fenomenologicamente disponíveis (desenho, perspectiva) produzidos a partir de uma maneira específica de produção. Essa maneira ou forma de produção será mais tarde fundamentada por Alberti a partir das elaborações geométricas, óticas e epistemológicas de pensadores ainda mais antigos, como Euclides, Alhazen e Aristóteles, ganhando o nome de construção legítima.

A menção anterior a Gombrich não é gratuita. Embora o trecho citado não deixe completamente evidente em que sentido sua proposta em Arte e Ilusão endossa a semiótica de Peirce, o historiador fará questão de esclarecer mais tarde em que consistirá a tarefa de compreender a história da arte em termos semióticos. Ao que me parece, Gombrich concebe a historicidade da arte através da ideia da invenção, repetição, transformação, retomada e também abandono de modos específicos de confecção dos signos em momentos específicos do tempo. ${ }^{5} \mathrm{E}$ isso exigirá igualmente que Gombrich in-

A introdução da noção de modos específicos de realizar o signo é, muito provavelmente, uma espécie de remédio para curar posições estereotipadas como o organicismo historiográfico de Vasari ou a periodização teleológica da história da arte hegeliana e a perspectiva de Alois Riegl que procurou fundamentar a historicidade da arte em termos de uma Kunstwollen. Ideia semelhante será, mais tarde, endossada por 
corpore em sua proposta àquela ideia avançada por Peirce (2005) sobre os modos de mediação do significado de um signo.

Em poucas palavras, creio que a diferença entre sinais e imagens está no contexto mental diferente que temos de adotar para compreendê-los. É muito conveniente para minha explicação o fato de que Magritte, um dos artistas mais inteligentes do século, gostava de refletir sobre essa diferença. Na pintura das duas telas emolduradas, uma é simplesmente uma mancha azul, a outra traz escrita a palavra "ciel". Podemos dizer que a primeira é uma imagem e a segunda são sinais. $\mathrm{Na}$ terminologia do filósofo americano Charles Peirce, a imagem também pode ser descrita como um sinal icônico, porque tem algo em comum com o seu significado ou denotação, a cor azul. A palavra "ciel" [por outro lado] é um sinal não-icônico; seu significado é puramente convencional, o mesmo ocorrendo com as quatro letras que a compõem. Se não soubéssemos francês e não conhecêssemos o alfabeto latino, só seria possível adivinhar o significado. Será que adivinharíamos necessariamente que a mancha azul representa o céu? Dificilmente. Ela poderia ser a amostra de um produto ou de uma tinta; porém, combinada com a palavra "ciel", nós acertadamente rejeitaríamos essas divagações. Tendo sido alertados, identificamos o céu. Não que isso nos impeça de distinguir entre reproduções mais ou menos fiéis ou mais ou menos convincentes de céu que conhecemos da história da arte. Nós não esperamos, normalmente, que a palavra "ciel" seja mais ou menos parecida com o céu. O significado dos signos é transmitido não por sua aparência geral, mas por aquilo que se conhece como características identificadoras (Gombrich, 2007, p. 18).

Fica, assim, evidente que Gombrich se encontra em alguma medida comprometido com a ideia de Peirce de que um signo qualquer (ou representâmen, na terminologia peirceana) apresenta diferentes modalidades de mediação de seu significado, organizadas em sucessivas tricotomias dentro da arquitetônica semiótica. Particularmente na segunda tricotomia, Peirce apresenta a ideia da mediação do significado de um signo enquanto Ícone, Índice ou Símbolo:

Um signo, ou representâmen, é aquilo que, sob certo aspecto ou modo, representa algo para alguém. Dirige-se a alguém, isto é, cria, na mente dessa pessoa, um signo equivalente, ou talvez um signo mais desenvolvido. Ao signo assim criado denomino interpretante do primeiro signo. O signo representa alguma coisa, seu objeto. Representa esse objeto não em todos os seus aspectos, mas com referência a um tipo de ideia que eu, por vezes, denominei fundamento do representâmen (Peirce, 2005, p. 46).

Umberto Eco no advento de sua Obra Aberta, em 1962, e sua insistência nos diferentes modos de produção, ou projetos operativos situados em tempos e espaços específicos, por detrás de cada obra de arte existente. 
E também:

Os signos são divisíveis conforme três tricotomias; a primeira, conforme o signo em si mesmo for uma mera qualidade, um existente concreto ou uma lei geral; a segunda, conforme a relação do signo para com o seu objeto consistir no fato de o signo ter algum caráter em si mesmo, ou manter alguma relação existencial com esse objeto ou em sua relação com um interpretante; e a terceira, conforme seu Interpretante representá-lo como um signo de possibilidade ou como um signo de fato ou como um signo de razão (Peirce, 2005, p. 51).

E ainda:

De acordo com a segunda tricotomia, um Signo pode ser denominado Ícone, Índice ou Símbolo. Um Ícone é um signo que se refere ao Objeto que denota apenas em virtude de seus caracteres próprios. [...] Um Índice é um signo que se refere ao Objeto que denota em virtude de ser realmente afetado por esse Objeto. [...] Um Símbolo é um signo que se refere ao Objeto que denota em virtude de uma lei (Peirce, 2005, p. 52).

Nesse sentido, parece-nos que Gombrich incorpora a segunda tricotomia de Peirce como um modo legítimo de pensar a arte e, mais, de explicar a sua historicidade. Uma imagem, compreendida enquanto signo, poderá ser interpretada como ícone se faz a mediação de seu significado através de uma referência ao objeto que resguarda os caracteres próprios desse objeto. Nesse sentido, a porção da pintura de Magritte que apresenta uma tela com manchas azuladas seria uma imagem icônica do céu real e existente porque emula algumas de suas características conhecidas, por exemplo, a variação entre tonalidades de azul em um dia determinado. Por outro lado, a porção da pintura que apresenta uma tela contendo as letras c, i, e, 1 e que formam o signo 'ciel', seria na interpretação de Gombrich uma imagem simbólica do céu porque recorre à lei da própria língua francesa que estabelece consuetudinariamente a junção dessas letras como a palavra 'ciel' e estabelece a designação dessa palavra ao objeto céu. Embora Gombrich recorra à tela de Magritte mais como uma oportunidade de discussão e de esclarecimento da semiótica de Peirce que como uma interpretação efetiva da própria pintura, o seu ponto parece bastante claro. Ele sugere que imagens, como as obras de arte, podem perfazer a mediação de seus significados enquanto ícones ou símbolos porque são signos e, portanto, estabelecem relações sucessivas com objetos, fundamentos e interpretantes. 




Figura 4

René Magritte, O palácio das cortinas, 1929

A imagem enquanto signo icônico, nos termos de Peirce e de Gombrich, é o que marca a nossa compreensão da arte ocidental desde o período clássico grego, quando as imagens passam a abandonar elementos simbólicos e a mediar seus significados através de uma referência aos caracteres próprios dos objetos referidos. A fabricação do signo imagético no período medieval é modificada e passa a estabelecer a mediação de seu significado novamente de modo simbólico. O quattrocento, por sua vez, apresenta a retomada da confecção das imagens como signos icônicos; essa retomada é reconhecida por Alberti no campo prático, que a formaliza através da noção de construção legítima e apresenta a iconicidade (o estilo naturalista) granjeado por essa construção como janela para o mundo; e, por sua vez, é também reconhecida por Vasari que, no campo histórico, entende-a como renascença do estilo clássico, através da qual o período efetua a sua efetiva rinascità.

Concluído esse desvio sobre as considerações historiográficas, proponho uma recolocação do trabalho fundamental de Vasari em seu As vidas, 
de 1550. Embora a proposta vasariana tenha logrado uma série de corolários que não aceitaríamos sem objetar nos dias de hoje (como, por exemplo, a sua hipótese evolutiva da história), ela também foi capaz de salientar através da sua ideia da historicidade em termos estilísticos que o Renascimento foi um período de retomada da confecção da imagem em termos naturalistas como fizeram os gregos. Desse modo, falar de uma maneira produtiva que é reincidente e que, de Cimabue a Michelangelo, é retomada e arrojada tecnicamente, significa também compreender a história a partir das técnicas de produção e das maneiras de fazer. Defender a variação das maneiras e dos estilos de fabricação da imagem enquanto fundamento da história da arte, prescindido de teses valorativas sobre essa variância ou de determinismos teleológicos em termos evolutivos, parece-me configurar um movimento importante de crítica às concepções de Vasari. Mas, também, de defesa daquilo que em sua proposta ainda é adequado e legítimo. Não tomamos, atualmente, a periodização estilística que a partir de Vasari passa a estruturar o funcionamento interno da história da arte como indício, ou como razão suficiente, de um progressivo desenvolvimento das artes rumo à perfeição imitativa viabilizada pela perspectiva e pela construção legítima. Distintamente disto, tomamos a periodização estilística, no espírito de Gombrich, unicamente enquanto um indício da certeza de uma variação sistemática das convenções e maneiras de produção das imagens. ${ }^{6}$

É através dessa compreensão mais refinada, capaz de fazer avançar um recredenciamento daquilo que ainda é legítimo em Vasari a partir do trabalho de Gombrich, que sugerimos a pintura dos séculos XVI e XVII - à parte das nomenclaturas usuais e que granjearam popularidade como, por exemplo, maneirismo, barroco, tenebrismo, rococó, etc. - enquanto mais um dos muitos episódios ecléticos da história da arte. Marcado pela presença concomitante de formas distintas de produção da imagem que correm em paralelo no leito comum das primeiras teorias sobre a arte em Platão e Aristóteles e nas primeiras tentativas de periodização da arte em Vasari. Em lar-

\footnotetext{
Volto a insistir que a ideia de uma certeza sobre a variância nos modos produtivos também se encontra no seminal trabalho de Umberto Eco, Obra Aberta, de 1962. Ali podemos encontrar a recuperação da ideia de poética como modo de produção, como projeto operativo, que circunscreve a feitura de uma obra de arte particular e que dá conta da intencionalidade do artista.
} 
ga medida é essa compreensão mais generosa das ideias vasarianas que nos permite dimensionar com maior cuidado, por exemplo, a pintura do século seguinte ao de Vasari. E isto porque a pintura do século XVII foi produzida nas intermitências de diferentes convenções de confecção imagética o que evidencia, reitero, outro dos muitos episódios ecléticos na história da arte. Fumaroli (1982), por exemplo, afirma que a pintura desenvolveu uma "verdadeira cultura pictórica entre 1630 e 1660 em Paris; o gosto respondia a diversas maneiras em voga, harmonizando-o com as várias sensibilidades e interesses que só uma capital receptiva a todos os humores espirituais como Paris poderia oferecer" (Fumaroli, 1982: 28). É interessante como Fumaroli sugere a formação dessa cultura pictórica francesa já em meados do século XVII como típica de um momento marcado pelo ecletismo artístico de diferentes estilos - as maneiras, de Vasari - mas, também, por diferentes parâmetros estéticos ou de gosto capazes de apreciar, interpretar e comparar o que era produzido em termos de pintura. No entanto, Fumaroli admite claramente que esse período eclético da arte francesa se dá quase um século depois de Vasari e das grandes inovações que esse último atribuí aos artistas italianos, já que no:

início do século XVII, o mecenato em relação às artes [ainda] não existia nem entre a burguesia parlamentar, erudita e austera, nem entre a velha aristocracia, um pouco mais inclinada aos festejos e celebrações sociais que compensavam a brutalidade das guerras civis. A pintura, contudo, exigia um verdadeiro ambiente educado e esclarecido de amantes das artes para se desenvolver; exigia pessoas treinadas em apreciar e em comparar talentos, coisa que havia existido durante o século XVI na Florença dos Medici, na Roma de Leo X e Clemente VII, e na Veneza dos mercadores aristocráticos (Fumaroli, 1982, p. 5).

O florescimento dos novos modos de produção dessa arte pictórica na França só encontrará um necessário ambiente de erudição, apreciação e mecenato anos mais tarde, instaurando uma espécie de Renascimento francês tardio em relação à pintura.

Durante o século XVII, Paris estava em vias de se tornar o que Roma havia sido para os artistas desde o final do século XV aquilo que, mais tarde, Goncourt chamaria de "o lar dos artistas", repleto de evocativas memórias e ilustres presenças do passado; ou ainda aquilo que Mario Praz, por sua vez, chamaria de "a casa da vida". O "espírito de lugar" parisiense demandava então que a 
capital francesa, o antigo bastião intelectual da cristandade medieval, se transformasse numa moderna Alexandria (Fumaroli, 1982, p. 6).

Dentro desse complexo ambiente de influências, referências e lembranças evocativas proporcionadas por uma certa consciência histórica e por uma capacidade de discriminação de diferentes maneiras artísticas, é que os nomes dos grandes mestres italianos - Giotto, Rafael, Leonardo Da Vinci e Michelangelo - serão constantemente comparados com outros parâmetros de confecção da imagem. Como, por um lado, a influência 'barroca' e inovadora de nomes como o do flamengo Rubens e do italiano Caravaggio e, por outro lado, a influência conhecida e familiar da arte gótica, medieval.

Gostaria, portanto, de sugerir, ampliando algumas das constatações de Fumaroli, que a pintura francesa do século XVII não é só marcada em seu ecletismo pela coexistência de modos tipicamente medievais e renascentistas no que diz respeito à fabricação imagética, mas também pela existência de uma terceira modalidade aprendida com Rubens e com Caravaggio. Particularmente, ambos pintores conseguem instilar na cultura pictórica uma nova forma de moldar a imagem que inicialmente prescinde da suprema exigência renascentista pela exatidão do desenho através da perspectiva e pela insistência daquilo que Hauser aponta como o efeito total da pintura do Renascimento, onde a imagem - seja ela uma Madonna, uma cena bíblica, ou um retrato aristocrático - constelava a presença de elementos adjacentes e cuja função perspícua consistia na montagem de todas situações do cenário na janela renascentista (Hauser, 2010: 280-281). Pois é o cenário, com seu ponto de fuga e planos secundários bem delimitados que suporta a criação do efeito total da pintura renascentista pela perspectiva pingendi. A insistência do trabalho do artista em pintar o cenário, para dentro do qual ingressa todo o conhecimento enciclopédico de arquitetura e toda a geometrização bem calculada de ortogonais e paralelas, é lentamente modulada por Rubens e por Caravaggio porque esses pintores aprendem a sugerir a ilusão de profundidade não somente através da perspectiva linear, mas também através da perspectiva atmosférica, ou melhor, tonal (Aumont, 1993: 63-64).

$\mathrm{Na}$ página seguinte encontramos o famoso afresco de Masaccio (figura 5) na Igreja de Santa Maria Novella, em Florença. Sua Santíssima Trin- 
dade é celebrada por artistas e historiadores do Renascimento como uma das mais impressionantes obras realizadas a partir dos cálculos da perspectiva, de modo que:

Se alguém se posta centralmente, de uma distância razoável da Santíssima Trindade e na altura média de uma pessoa, a ilusão criada pela obra é de que pessoas de tamanhos reais estão dispostas em um espaço arquitetônico real e que se estende muito além daquela superfície de parede onde o afresco está pintado. Parece, portanto, um espaço construído segundo a lógica da perspectiva linear (Talbot, 2003, p. 77).

É importante mencionar que a perspectiva linear é granjeada, como vimos anteriormente, mediante a composição geométrica de uma série de elementos coadjuvantes em relação ao tema bíblico do afresco. As colunas, o frontispício, o domo, os degraus do altar, os ornamentos arquitetônicos são todos elementos que, embora não remetam diretamente ao tema escolhido por Masaccio, presentificam-se como elementos garantidores da adesão do artista à convenção renascentista. Esse modo composicional de trabalhar com a confecção da imagem pode ser encontrado em outras pinturas e afrescos do período, sobretudo a partir do século XV. 
Perspectiva Filosófica, vol. 45, n. 2, 2018

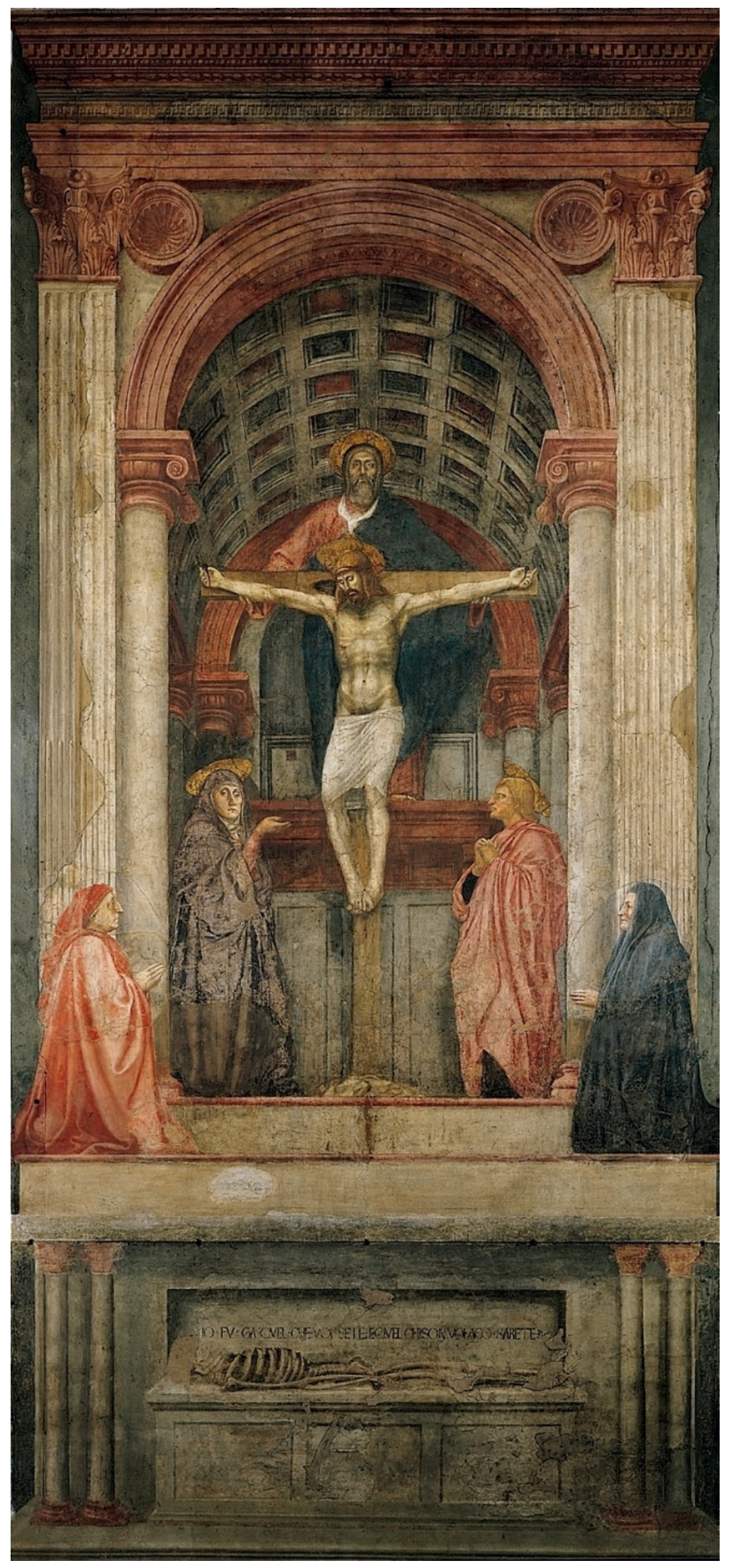

Figura 5

Masaccio, Santíssima Trindade, 1427 
Perspectiva Filosófica, vol. 45, n. 2, 2018

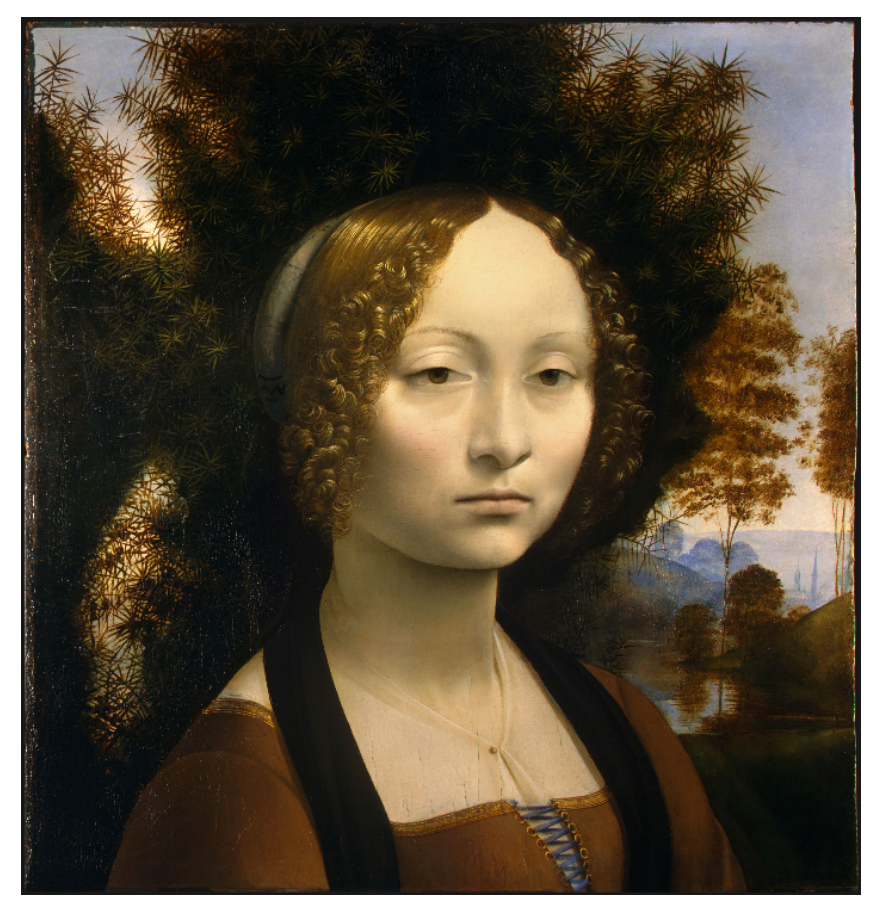

Figura 6

L. Da Vinci, Retrato de Ginevra de' Benci, 1478

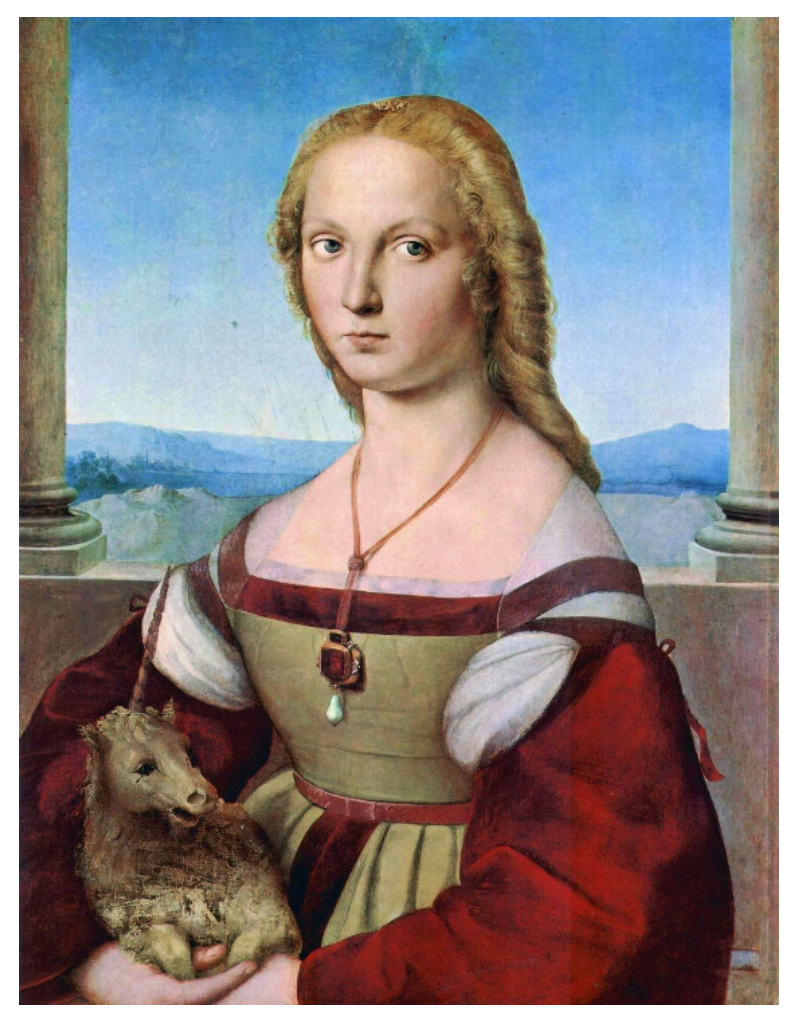

Figura 7

Rafael, Mulher com unicórnio, 1506 
Perspectiva Filosófica, vol. 45, n. 2, 2018

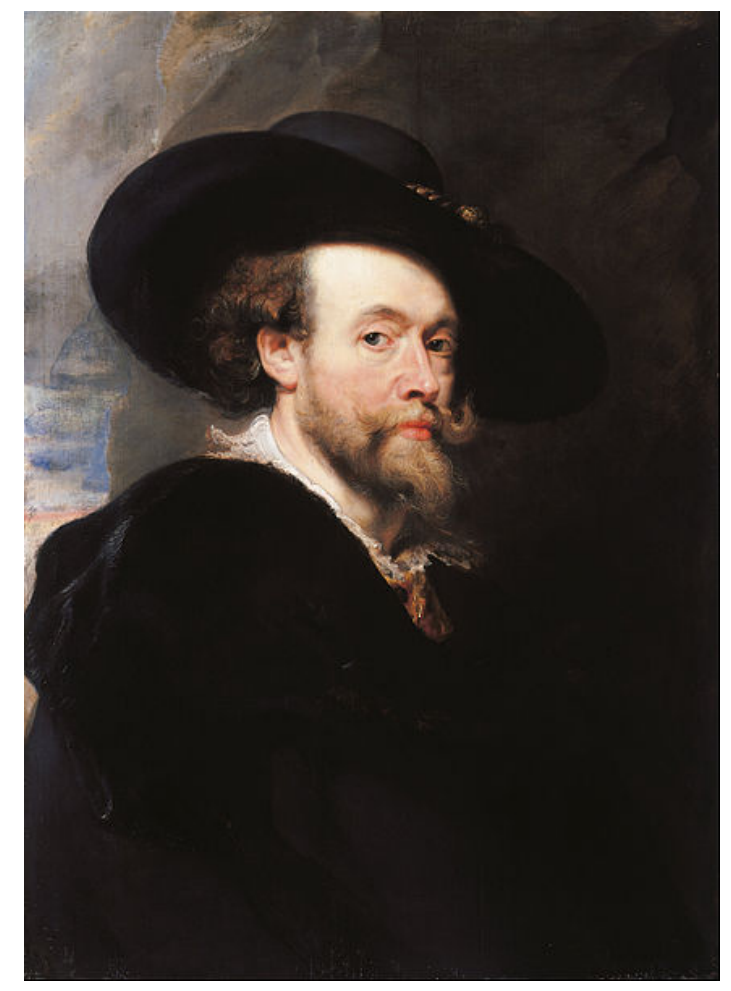

Figura 8

P. P. Rubens, Autorretrato, 1623

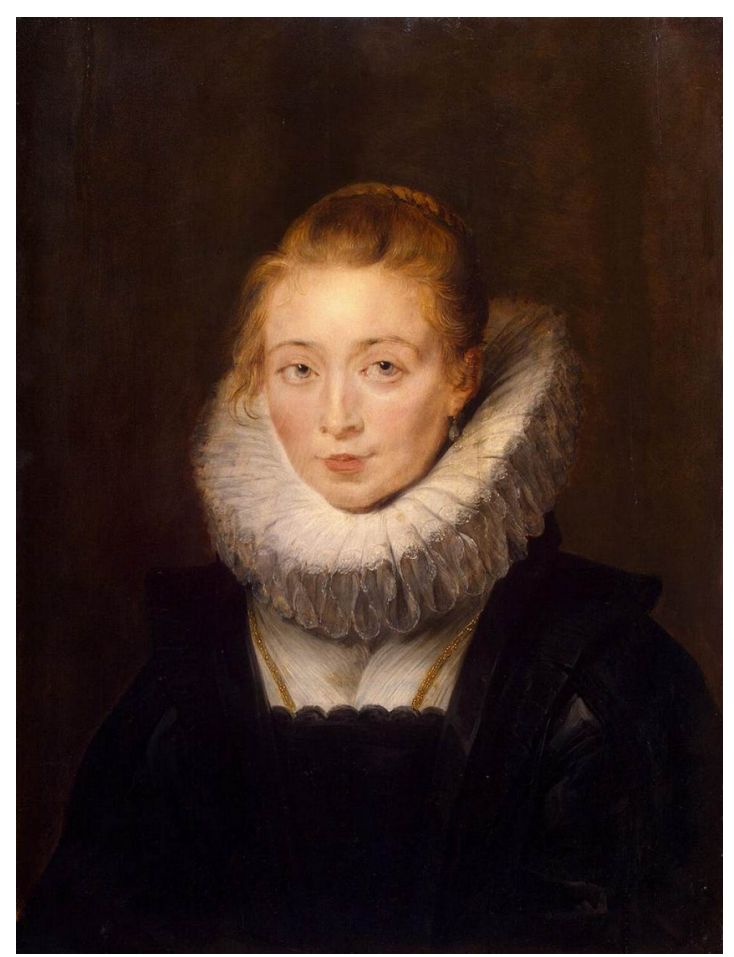

Figura 9

P. P. Rubens, A dama de honra, 1625 
Perspectiva Filosófica, vol. 45, n. 2, 2018

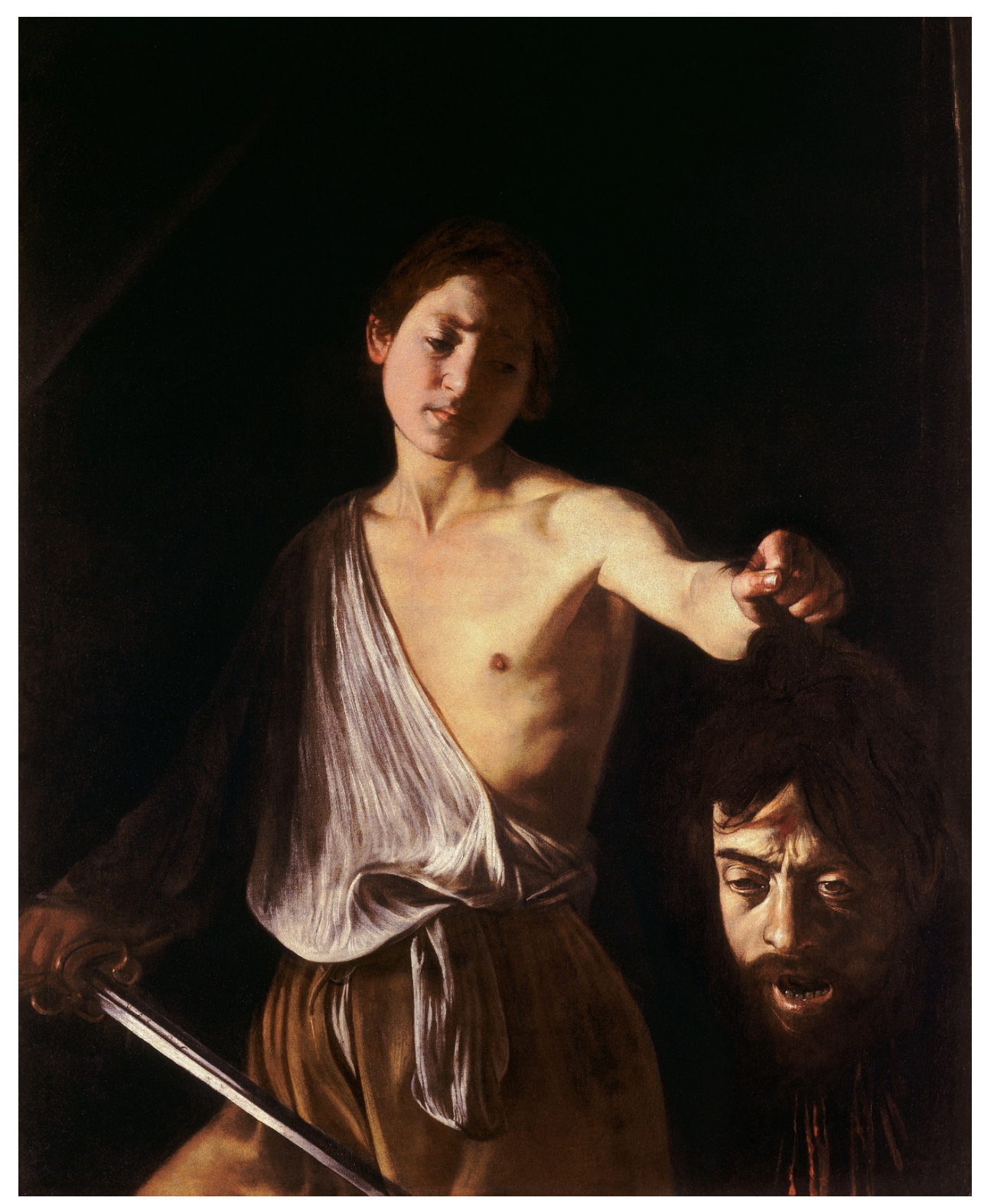

Figura 10

Caravaggio, Davi com a cabeça de Golias, 1610 


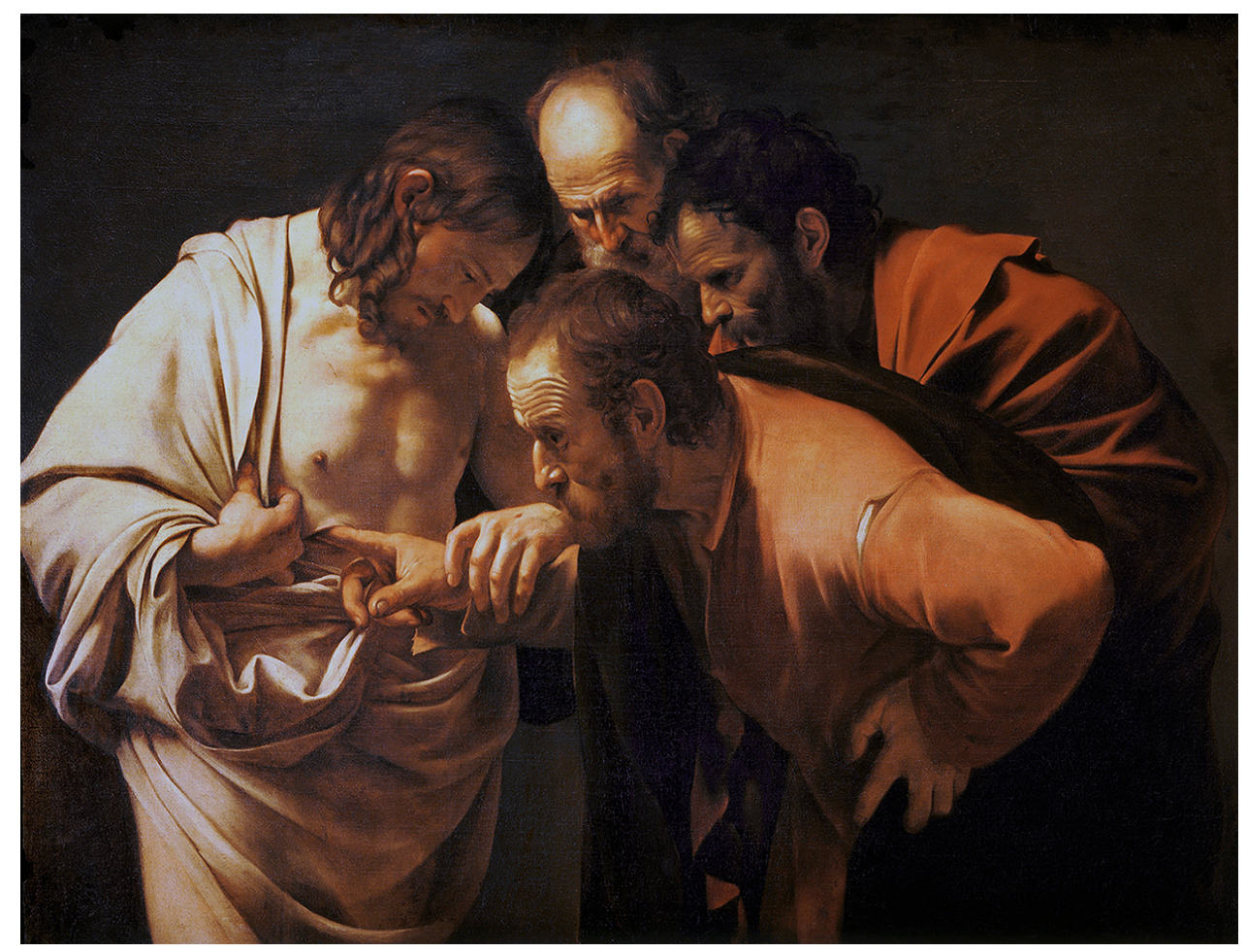

Figura 11

Caravaggio, A incredulidade de São Thomé, 1602

Encontrar-se-ão quase sempre a presença desses elementos auxiliares, sejam eles arquitetônicos ou paisagísticos, aos quais o artista recorre como maneira de respeitar a construção legítima e de garantir, plasticamente, a ilusão de tridimensionalidade das imagens feitas em estruturas bidimensionais. De modo similar, os elementos de segundo plano, ou de fundo, presentificam-se para garantir o efeito de perspectiva, perfazendo a ilusão de profundidade e de escorço do primeiro plano. O trabalho de paisagem, no retrato de Da Vinci (figura 6) e no de Rafael Sanzio (figura 7) apresentam claros pontos de fuga, elemento essencial da perspectiva linear, corporificados em elementos paisagísticos ou arquitetônicos.

Entretanto, dois retratos mais recentes de Rubens (figuras 8 e 9) prescindem de uma composição tipicamente renascentista na qual elementos do plano de fundo comparecem claramente distinguidos e reconhecíveis. Não há nestes retratos um trabalho de confecção da imagem que constele os elementos de cenário e que, para os parâmetros antigos como os de Vasari e de Alberti, eram essenciais para a feitura do desenho. Como, en- 
tão, Rubens - e também Caravaggio, nas figuras 10 e 11 - conquistam o naturalismo das pinturas do Renascimento sem a composição do cenário, do plano de fundo e, consequentemente, dos pontos de fuga distinguíveis e necessários para a perspectiva linear?

A resposta, parece-me, consiste em afirmar que tanto Rubens quanto Caravaggio ao se interessarem mais pelo aspecto técnico da cor e menos pelo aspecto do desenho (essencial para a composição legítima), passam a explorar na pintura outras maneiras de confeccionar a imagem e, nesse sentido, rearticulam convenções imagéticas. Assim, o autorretrato de Rubens (figura 8) e a pintura de Caravaggio (figura 10) apresentam profundidade não através do cálculo composicional do desenho via perspectiva linear, mas pela iluminação ou pelo obscurecimento de porções específicas da pintura através do chiaroscuro que é, sobretudo, uma técnica da cor e da tinta, e não uma técnica da composição e do desenho. Vemos e entendemos que Davi (figura 10) encontra-se em uma posição inclinada, como se o seu braço que empunha a espada estivesse se afastando de um 'primeiro plano' porque ele não recebe a mesma luz que o restante do torso de Davi. De um ponto de vista técnico, isso significa dizer que o braço de Davi não foi pintado com a mesma escala cromática e, portanto, com as mesmas cores que o seu torso. $\mathrm{O}$ ponto aqui consiste em afirmar que a modelagem da imagem, o fato de que ela aparece para nós como feita de carne e osso, volume e extensão, não se dá mediante o cálculo daquilo que no gradeamento rígido da perspectiva linear deve estar no primeiro ou no segundo plano; mas, distintamente, dá-se mediante a conquista de uma luz interna ao próprio suporte. E a luz na pintura é, necessariamente, um trabalho da cor e da tinta, não do desenho. O efeito de dramaticidade transmitido por esse tipo de convenção, a da modelagem via chiaroscurso, é muito maior, porque a imagem abandona aquela rigidez posada, calculada e estática das imagens renascentistas e ingressa numa movimentação e numa gestualidade típicas do trabalho da cor e da luz.

[...] por que Caravaggio causou esse senso de choque e de perplexidade? A resposta se encontra menos em um estudo da genialidade do pintor e mais em seu método, que pareceu por um tempo resolver de uma vez por todas os dilemas de uma arte humanista exemplificada mais agudamente pela pintura. $\mathrm{O}$ dilema 
consistiu no conflito entre a imitação acadêmica da antiguidade e a observação direta da natureza. [...] A arte de Caravaggio não tem nada a ver com o realismo em seu sentido moderno, que pressupõe uma atitude sensualista e empírica em relação ao mundo, algo muito anacrônico quando aplicado ao Renascimento. A visão de Caravaggio era, ao mesmo tempo, humanista e cristã. Humanista porque ele percebeu a natureza humana através das formas da antiga estatuária, ao mesmo tempo em que as vivificou com toda a dramaticidade da luz e da sombra que as preservou de uma frieza marmórea. Foi um humanismo concentrado em corpos e grupos de pessoas, mas aliviado dos ensinamentos enciclopédicos de Leonardo que se associava com uma honra da pintura. Um senso de espaço substituiu o conhecimento de arquitetura, perspectiva e arqueologia (Fumaroli, 1982, p. 20).

Rubens e, sobretudo, Caravaggio são responsáveis pela introdução de uma convenção pictórica da dramaticidade e do movimento não porque submeteram sua fabricação imagética aos preceitos de Alberti e de Vasari, mas porque ao recuperarem o chiaroscuro, experimentando-o à revelia do desenho, mostraram-nos a possibilidade de uma nova maneira de confecção da imagem. Chamar atenção, como tenho feito, ao aspecto metodológico de feitura das imagens e também às mudanças que essa feitura atravessou ao longo dos séculos XV, XVI e XVII é o que me parece explicar com maior exatidão essa insistência eclética na pintura francesa do século XVII. E isso porque as inovações pictóricas de Rubens e Caravaggio prontamente granjeiam imensa popularidade no contexto francês do período, embora a influência da pintura renascentista não tenha sido abandonada. E é isso que também explica, de certo modo, o ecletismo pictórico do século XVII na França onde, por um lado, encontramos as Escolas Caravaggistas e, por outro lado, encontramos artistas adeptos do grande estilo clássico da pintura renascentista e dos princípios de Vasari e Alberti.

Nesse sentido, é possível encontrar na pintura francesa a partir da metade do século XVII uma verdadeira tensão artística no modo de produção pictórica entre artistas Caravaggistas e artistas 'renascentistas'. Por um lado, Georges de La Tour (1593 - 1652) e Phillippe de Champaigne (1602 1674) foram os grandes representantes franceses da escola Caravaggista e, por outro, Nicolas Poussin (1594 - 1665) foi o maior representante de uma pintura ao modo renascentista. Hipóteses biográficas pretenderam explicar a proeminência de um modo de produção renascentista em Poussin, explicando sua pintura em função de ter passado boa parte de sua vida na Itália, onde 
a herança do período helênico é mais evidente e impressionante, as ruínas da antiguidade clássica foram preservadas à céu aberto e as primeiras academias de desenho e pintura remontam ao Renascimento. É inegável, contudo, que a obra de Poussin apresenta elementos distintos que sugerem essa influência. A figura 12, uma obra de 1638, é um bom exemplo da presença deles.

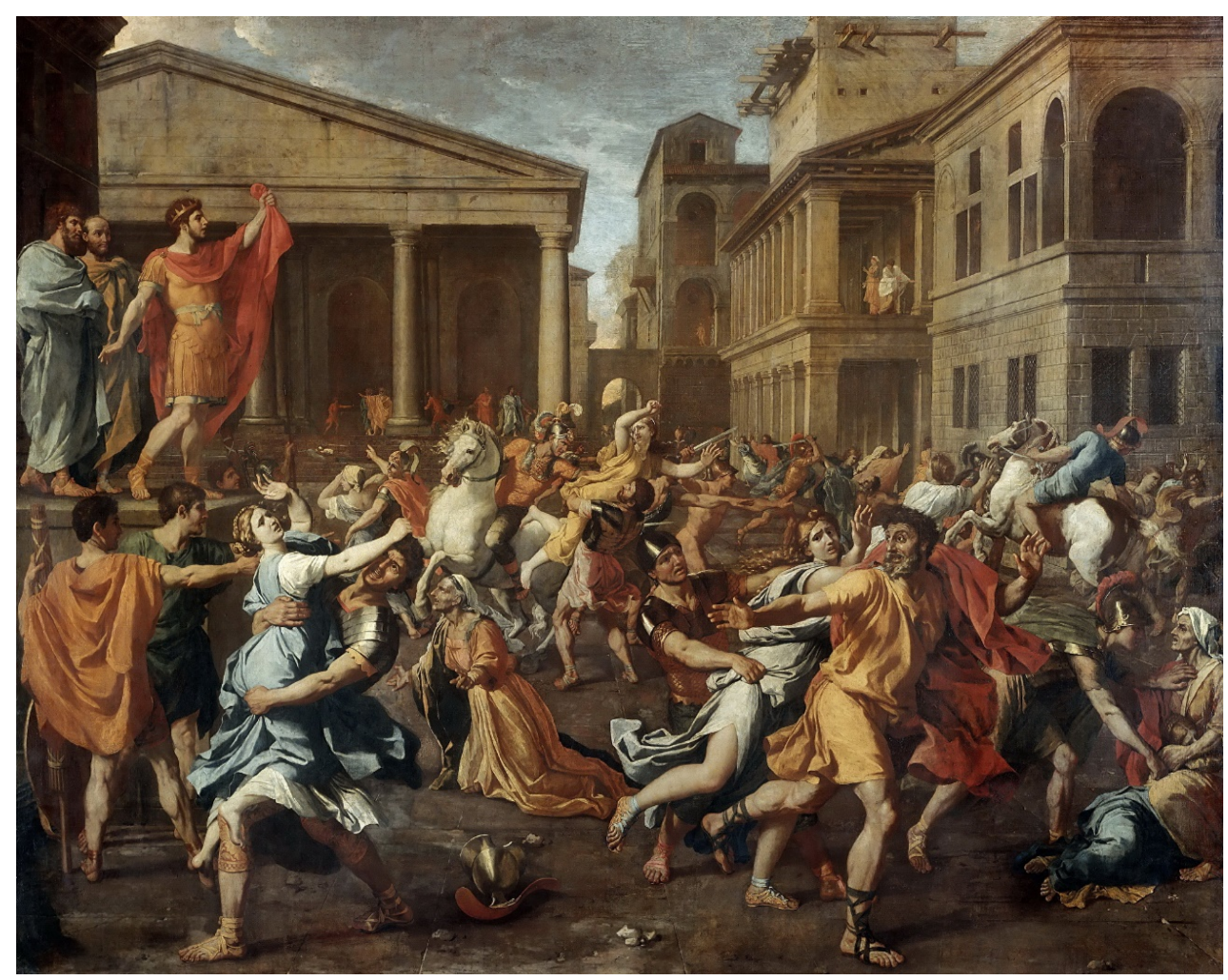

Figura 12

Nicolas Poussin, O rapto das Sabinas, 1638

Em O rapto das Sabinas de Poussin encontramos, além do tema clássico com suas referências mais evidentes e sugestivas da antiguidade, também o emprego da perspectiva linear, com seu ponto de fuga bem delimitado e sustentado pela complexa composição arquitetônica na forma de intrincadas construções de cenário e de plano de fundo. Diferentemente, em Georges de La Tour (figura 13) e em Phillippe de Champaigne (figura 14), encontramos uma atenção muito maior aos elementos da modelagem do corpo através do jogo de luz e de sombra, bem como uma atenção muito maior à cor; isso atesta que a confecção da imagem entre eles não se dá dentro da 
Perspectiva Filosófica, vol. 45, n. 2, 2018

convenção clássica, mas sobretudo através do chiaroscuro e da experimentação tonal e rítmica viabilizadas unicamente pela cor. Gostaria de sugerir, também, que ambos pintores franceses compartilharam a consciência de que a pintura pode ser realizada mediante outras convenções de fabricação imagética e, em certo sentido, plasmaram essa consciência intencionalmente em seus trabalhos com bastante clareza.

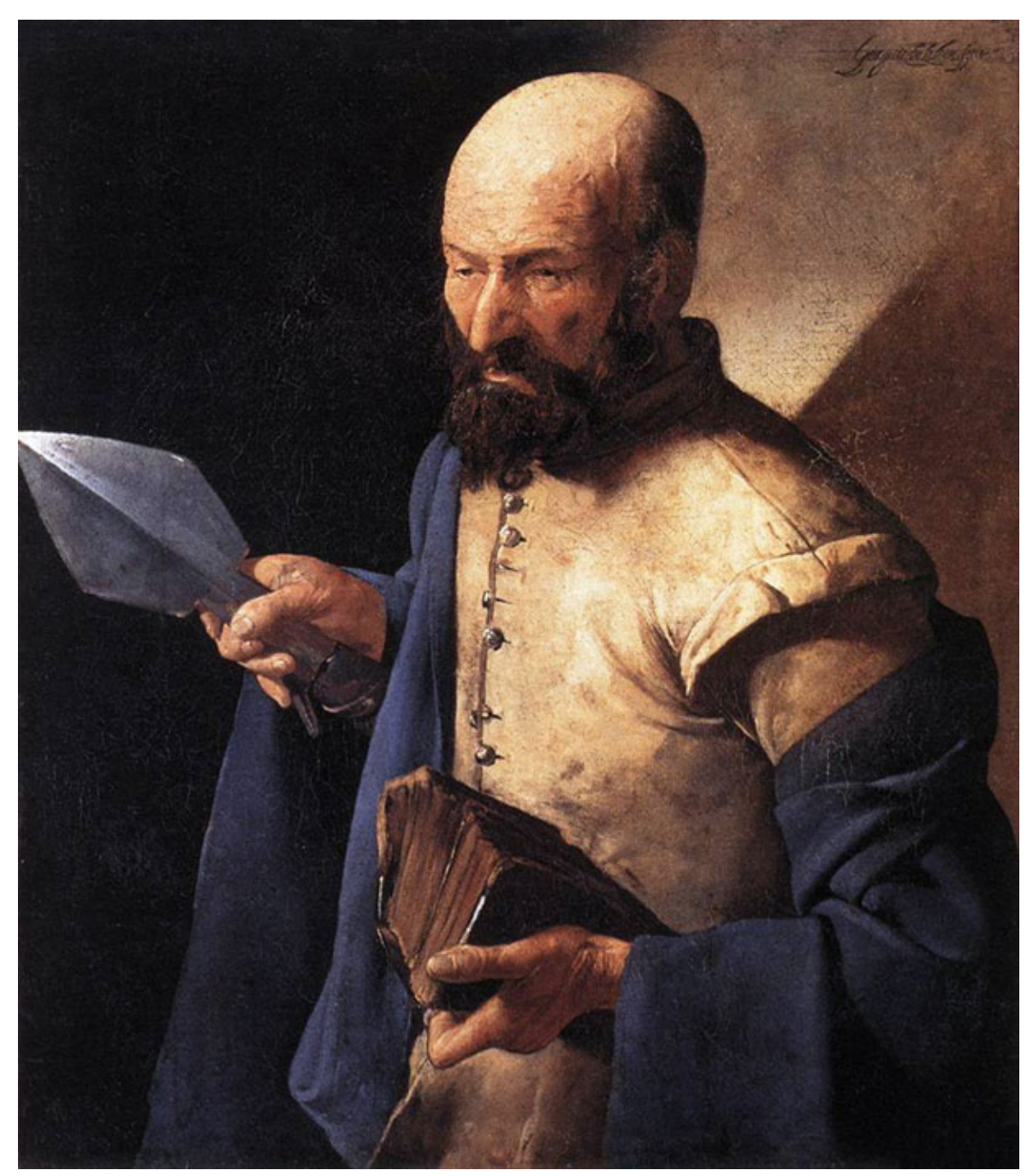

Figura 13

Georges de La Tour, São Tomé, 1630 


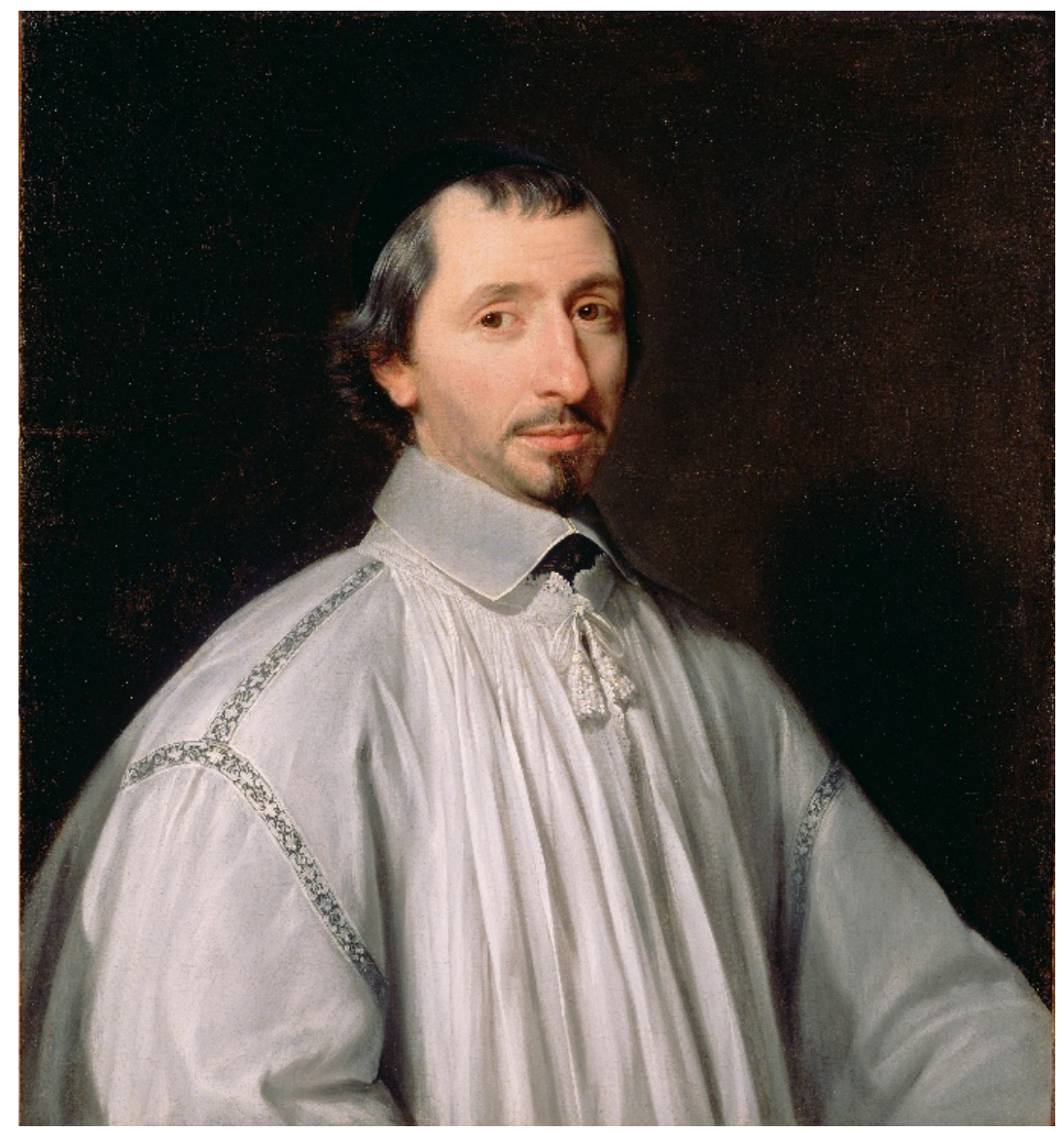

Figura 14

Phillippe de Champaigne, Antoine Singlin, 1649

Nas figuras 13 e 14 encontramos claramente sugerido o trabalho da luz e de como ela se comporta quando atinge determinadas superfícies causando, consequentemente, dadas as leis da refração, áreas de sombreamento. O segundo plano das pinturas de Georges de La Tour e de Phillippe de Champaigne apresentam ao contemplador uma espécie de perspicaz investigação técnica da luz realizada via trabalho pictórico. Especialmente nas obras de Georges de La Tour, essa motivação pela investigação poética, realizada via arte, via pintura, sobre o comportamento da luz e da sombra pode ser notada na experimentação técnica da tinta, no trabalho das cores, na pincelada e no impasto (termo que designa a quantidade de tinta depositada sobre uma área específica da pintura). É impressionante na obra de Georges de La Tour a quantidade expressiva de pinturas que, ao preconizarem o trabalho do chiaroscuro típico das escolas Caravaggistas, são capazes de incorporar igualmente uma verdadeira problematização técnica sobre o 
comportamento da luz. Diferentes fontes de luz, diferentes situações luminosas e diferentes poses e cenários são, em sua maioria, feitos como estudos da tonalidade pictórica.

É interessante notar que a fonte de luz nas obras de Georges de La Tour comparece enquanto um dos elementos centrais da pintura; ora sendo claramente indicada, como no caso das figuras 16 e 17, ora apenas sugerida em seu velamento, por detrás das mãos de uma personagem ou de outro objeto. Isso, parece-me, desempenha um papel diferencial em cada um dos quadros porque a refração da luz nestes objetos mais próximos (a mão, o pergaminho, etc.) ilumina com ainda mais intensidade os objetos vizinhos a ela. No caso das figuras 15 e 18, onde a vela é apenas imaginada pelo contemplador, as figuras centrais, o jovem cantor ou São Jerônimo, acolhem também a refração da luz exercida respectivamente pela página do livro e pelo pergaminho. A diferença, portanto, entre mostrar ao contemplador ou apenas fazê-lo entrever a fonte luminosa consiste em realizar uma pintura de dispersão ou de concentração da luz. Assim, pintar sucessivamente essas modulações luminosas, explorando situações diversas e contextos diferentes e que exigem, por parte do artista, reflexão em relação a como modelar os corpos e um certo ratio, um cálculo, em relação ao comportamento da luz, parece-me consistir num verdadeiro trabalho investigativo e experimental de uma maneira distintiva de pensar e de executar o trabalho artístico e a fabricação da imagem.

Algo muito diferente, portanto, que iniciar a pintura pelo cálculo da perspectiva e pelo desenho, geometricamente planejado, dos elementos que ingressam num primeiro plano, mais agigantados, e num segundo plano, já mais diminuídos. A feitura da imagem desde a sua concepção passa, com esses artistas por outros critérios e por outro preparo técnico. Inclusive outros critérios criativos. Embora Georges de La Tour tome o chiaroscuro e a inspiração Caravaggista enquanto mote artístico de boa parte de sua obra, é importante mencionar que as convenções clássicas de montagem da pintura não desaparecem. A maneira da construção legítima de Alberti e de Vasari continuou, durante o século XVII, a ser aplicada, inclusive na obra de pintores da escola Caravaggista, como é o caso de Phillippe de Champaigne. Ou, então, nunca deixou de ser aplicada como prerrogativa essencial da pintura, 
como é caso de Nicolas Poussin. Ainda assim, chamar a atenção para aquilo que há de distintivo em de Champaigne e em de La Tour em comparação com Poussin e com toda a tradição de pintura do Quattrocento consiste, em minha sugestão, num exercício salutar de compreensão de que a arte não evoluí ou entra em declínio conforme sugeriu Vasari no século XVI com sua hipótese orgânica sobre o fundamento histórico da pintura. Mas sim de que ela muda sobretudo em seus modos de construção, em suas técnicas de confecção e em suas experimentações intra-artísticas. E essa mudança exige, consequentemente, uma revisitação de nossas expectativas teóricas e de apreciação em relação a arte.

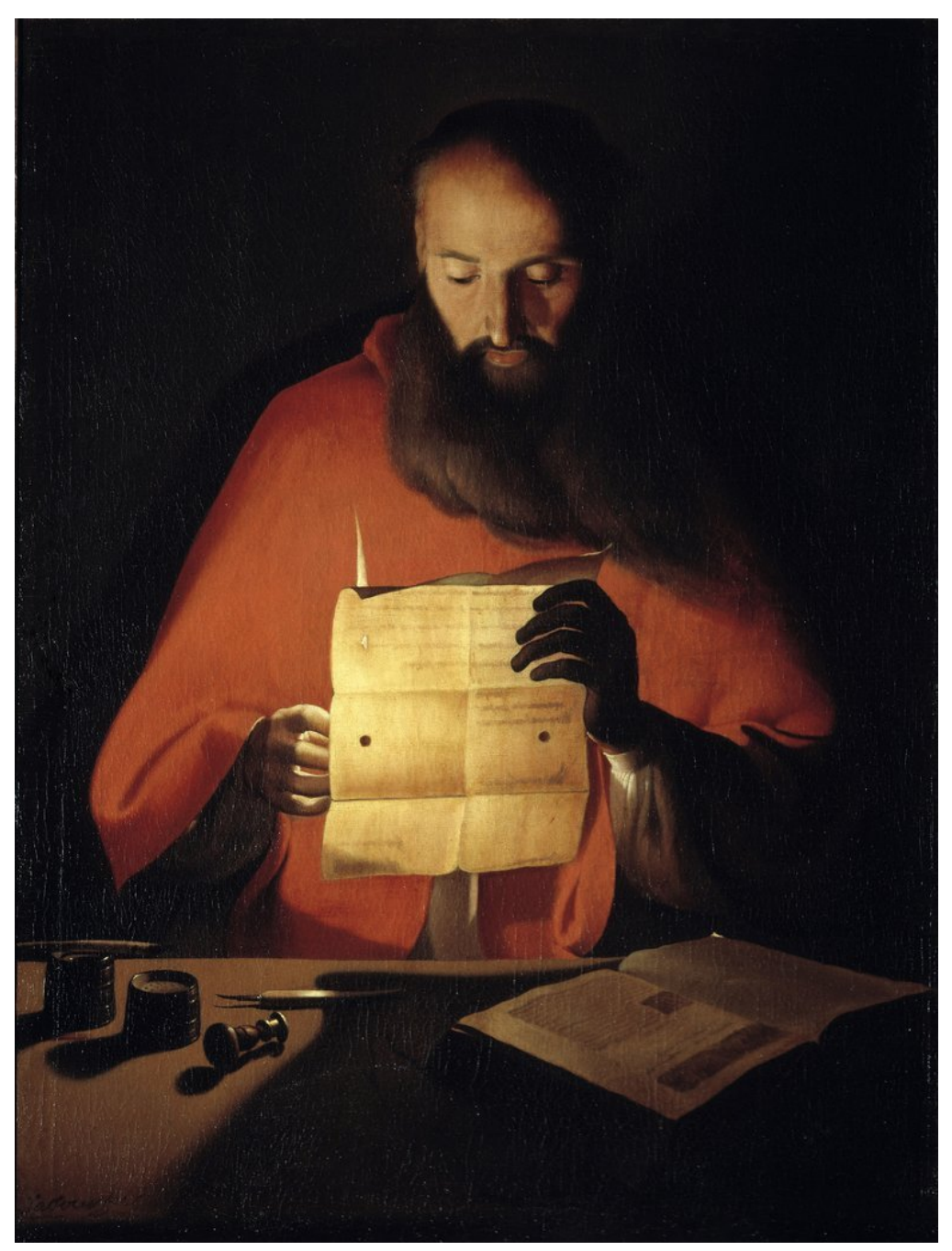

Figura 15

G. de La Tour, São Jerônimo, 1650 
Perspectiva Filosófica, vol. 45, n. 2, 2018



Figura 16

G. de La Tour, Mulher pegando uma pulga, 1638

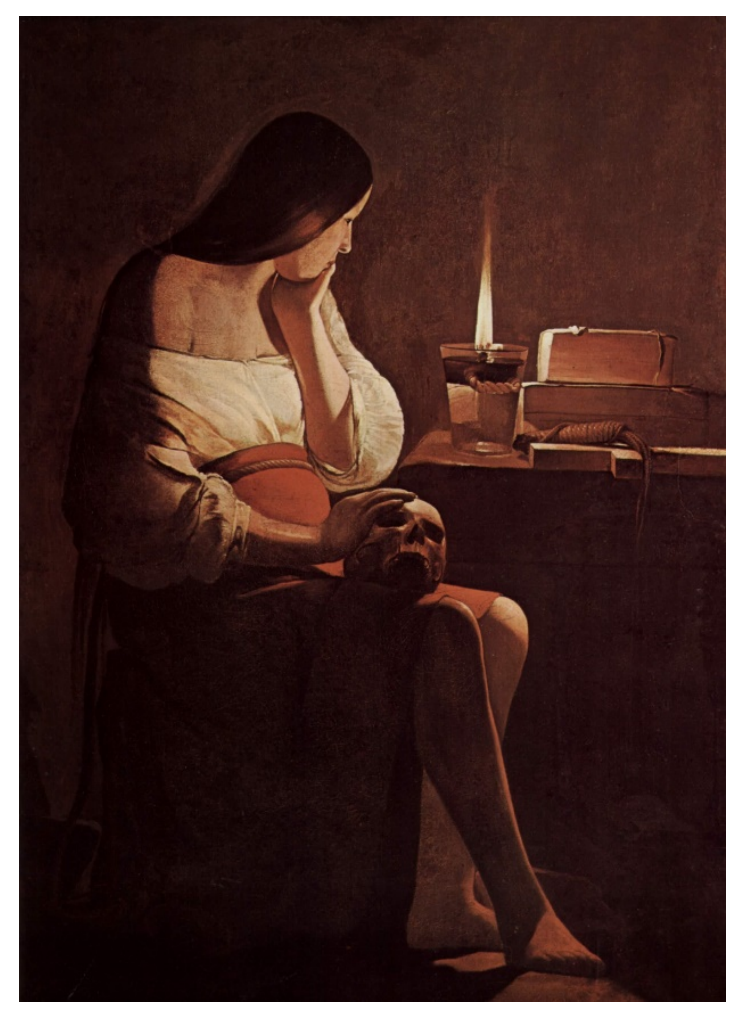

Figura 17

G. de La Tour, Madalena à luz bruxuleante, 1637 


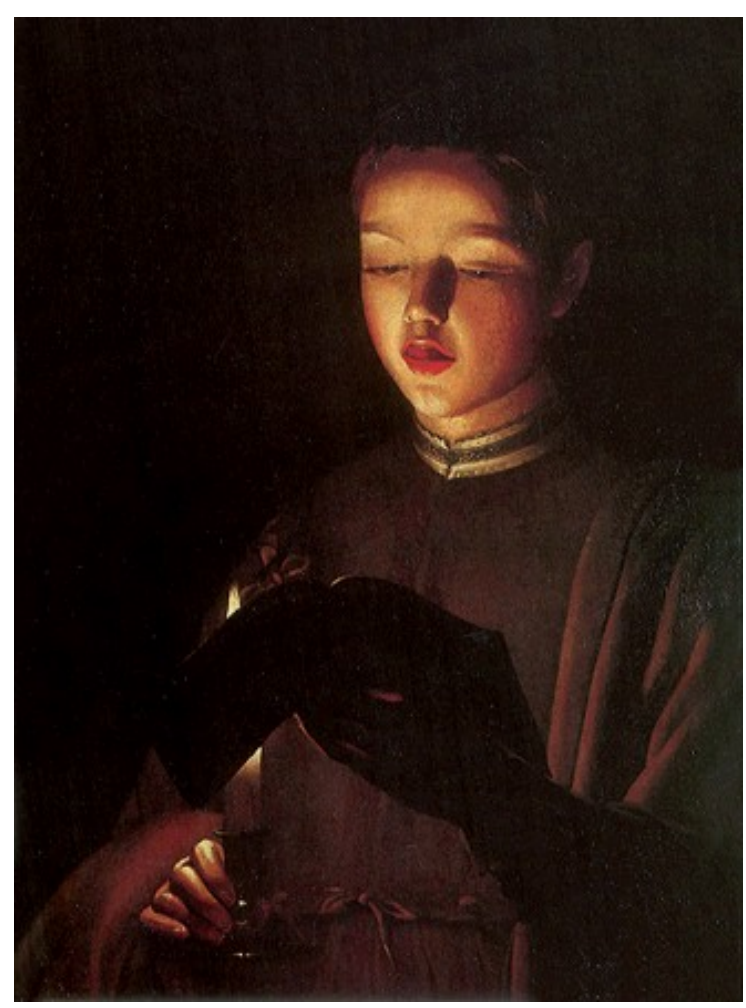

Figura 18

G. de La Tour, O jovem cantor, 1645

\section{Encerramento}

Pretendi ao longo do texto problematizar as relações, por vezes tomadas como óbvias, entre as artes pictóricas e percepção visual a partir da consolidação clássica de um dos mais relevantes parâmetros de confecção imagética na arte ocidental, a saber, a construção legítima de Alberti durante o Renascimento. Procurei situá-la, a partir da genealogia de Darrigol, dentro de uma longa tradição de pensadores que teorizaram distintamente sobre aspectos epistemológicos da percepção (Platão, Aristóteles, Francis Bacon) e sobre as bases matemáticas e os fundamentos geométricos da perspectiva e da ótica (Euclides, Ptolomeu e Alhazen) enquanto responsável pelo primeiro empreendimento de aplicação prática dessas doutrinas na técnica da pintura e na confecção das imagens naturalistas ou, retomando Peirce e Gombrich, de imagens icônicas.

Vasari foi também discutido no intuito de chamarmos atenção para o fato de que foi, em larga medida, a contribuição de Alberti que motiva um século depois a primeira proposta de periodização da arte em termos de uma 
historiografia estilística, com a introdução de categorias estruturantes da história como, por exemplo, a maneira, o modo e o estilo. Procurei, também, deflacionar algumas posições assumidas por Vasari em relação à natureza da história da arte ao propor sua releitura a partir da importante contribuição contemporânea de Gombrich em Arte e Ilusão. Esse, por sua vez, ao incorporar a semiótica de Peirce, oferece-nos uma concepção de historicidade para a arte em termos de modificações sucessivas nos modos de confeccionar as imagens e nos parâmetros de contemplação, interpretação e avaliação da arte. Nesse sentido, é Gombrich que faz um credenciamento daquilo que, em Vasari, é ainda admissível.

Por fim, procurei sugerir, num espírito gombrichniano, que uma das marcas distintivas da pintura do século XVII foi, em função da influência colossal de Caravaggio na pintura ocidental, uma revisitação da construção legítima de Alberti e uma preconização do trabalho da cor, da luz e da sombra. Nesse sentido Georges de La Tour é, para o período, o representante francês do Caravaggismo que mais reelaborou poeticamente as novas prerrogativas da pintura ao empreender em sua obra uma vasta investigação pictórica e técnica sobre o comportamento da luz e suas relações com a modelagem e a formação imagética. Parece-me, portanto, que a pintura de La Tour não somente prenuncia (em comparação a de Poussin) as tensões dicotômicas que serão mais tarde tão prementes na pintura francesa do século XIX entre o colorismo de Delacroix e o academicismo de Ingres e Bouguereau, mas também dá suporte ao projeto Caravaggista de pensar a tonalidade como outra construção legítima na pintura.

\section{Referências}

ALBERTI, Leon. Da Pintura. Campinas: Editora da Unicamp, 1999.

ALBERTI, Leon. Della Pittura. Milão: Società tipografica de'Classici italiani, $1804 . \quad$ Disponível em: https://archive.org/details/dellapitturaedel00albe/page/n177. Acesso em: 16/01/19.

ARISTÓTELES. De Anima. Tradução de Maria Cecília Gomes dos Reis. Editora 34: São Paulo, 2012. 
AUMONT, Jacques. A Imagem. São Paulo: Editora Papirus, 1993.

BAXANDALL, Michael. Painting and Experience in Fifteenth Century Italy - A primer in the social history of pictorial style. Oxford: Oxford University Press, 1988.

BURCKHARDT, Jacob. A cultura do Renascimento na Itália. Brasília: Editora da UnB, 1991.

BURKE, Peter. The Italian Renaissance: Culture and Society in Italy. New Jersey, Princeton University Press, 1994

CORRADA, Manuel. Visual Knots: Concerning Geometry and Visuality in the Work of Marcel Duchamp. In Michele Emmer (Ed.), The Visual Mind. Massachusetts: MIT Press, 2005, p. 309 a 334.

DARRIGOL, Oliver. A History of Optics: From Greek Antiquity to the Nineteenth Century. Oxford: Oxford University Press, 2012.

FUMAROLI, Marc. Des leurres qui persuadent les yeux. In ROSENBERG, Pierre. France in the Golden Age: Seventeenth-Century French Paintings. New York: MET, 1982.

GOMBRICH, Ernst. Arte e Ilusão. São Paulo: Martins Fontes, 2007.

HAUSER, Arnold. História Social da Arte e da Literatura. São Paulo: Martins Fontes, 2010.

KING, Peter. Thinking About Things - Singular Thought in the Middle Ages. In KLIMA, Gyula (Ed.) Intentionality, Cognition and Mental Representation in Medieval Philosophy. Fordham University Press: Nova York, 2015.

PANOFSKY, Erwin. La perspective comme forme symbolique. Paris: Minuit, 1975

PEIRCE, Charles. Semiótica. São Paulo: Perspectiva, 2005.

TALBOT, Richard. Speculations on the origins of linear perspective. In Nexus Network Journal, volume 5, número 1, 2003, p. 64 a 98. Disponível em: https://link.springer.com/article/10.1007/s00004-002-0005-5. Acesso em: 16/01/2019.

VASARI, Giorgio. The lives of the artists. New York: Oxford University Press, 1991. 